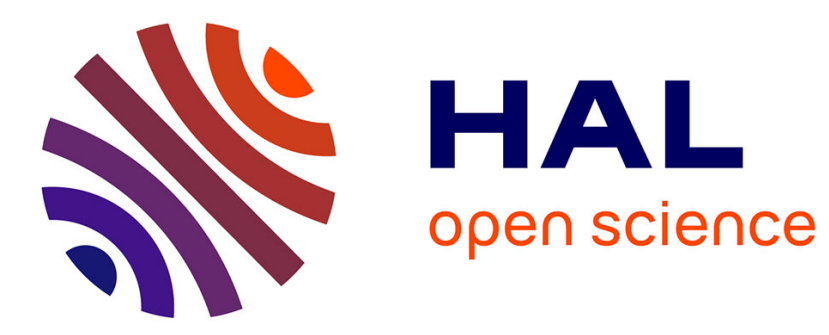

\title{
Complex life cycles of multicellular eukaryotes: New approaches based on the use of model organisms
}

Susana Coelho, Akira F Peters, Bénédicte Charrier, Denis Roze, Christophe Destombe, Myriam Valero, J. Mark Cock

\section{- To cite this version:}

Susana Coelho, Akira F Peters, Bénédicte Charrier, Denis Roze, Christophe Destombe, et al.. Complex life cycles of multicellular eukaryotes: New approaches based on the use of model organisms. Gene, 2007, 406 (1-2), pp.152 - 170. 10.1016/j.gene.2007.07.025 . hal-01926745

\section{HAL Id: hal-01926745 \\ https://hal.science/hal-01926745}

Submitted on 18 Dec 2020

HAL is a multi-disciplinary open access archive for the deposit and dissemination of scientific research documents, whether they are published or not. The documents may come from teaching and research institutions in France or abroad, or from public or private research centers.
L'archive ouverte pluridisciplinaire HAL, est destinée au dépôt et à la diffusion de documents scientifiques de niveau recherche, publiés ou non, émanant des établissements d'enseignement et de recherche français ou étrangers, des laboratoires publics ou privés. 


\section{Complex life cycles of multicellular eukaryotes: new approaches based on the use of model organisms}

Susana Coelho $^{\mathrm{a}}$, Akira F. Peters ${ }^{\mathrm{a}}$, Bénédicte Charrier ${ }^{\mathrm{a}}$, Denis Roze $^{\mathrm{b}}$, Christophe Destombe $^{\mathrm{b}}$, Myriam Valero ${ }^{\mathrm{b}}$, J. Mark Cock $^{\mathrm{a}}$ *

${ }^{\mathrm{a}}$ The Marine Plants and Biomolecules Laboratory, UMR 7139 Centre National de la Recherche Scientifique and Université Pierre et Marie Curie, Laboratoire International Associé Dispersal and Adaptation in Marine Species, Station Biologique de Roscoff, Place Georges Teissier, BP74, 29682 Roscoff Cedex, France.

${ }^{\mathrm{b}}$ Evolution et Génétique des Populations Marines, UMR 7144 Centre National de la Recherche Scientifique and Université Pierre et Marie Curie, Laboratoire International Associé Dispersal and Adaptation in Marine Species, Station Biologique de Roscoff, Place Georges Teissier, BP74, 29682 Roscoff Cedex, France.

* Corresponding author. Tel.: +332982923 60; fax: +33298292385.

E-mail address: cock@sb-roscoff.fr (J.M. Cock).

Keywords: Arabidopsis thaliana; gametophyte; Ectocarpus siliculosus; life cycle; model organism; ploidy; sporophyte 
Abbreviations: AGP18, ARABINOGALACTAN PROTEIN 18; Ds, Dissociator; LEC1, LEAFY COTYLEDON1; LEC2, LEAFY COTYLEDON2; MADS, MCM1/AGAMOUS/DEFICIENS/SRF; SERK, SOMATIC EMBRYOGENESIS RECEPTOR KINASE1; SPL, SPOROCYTELESS; ZmSERK, Zea mays SOMATIC EMBRYOGENESIS RECEPTOR KINASE1

Abstract

A wide variety of life cycles can be found in the different groups of multicellular eukaryotes. Here we provide an overview of this variety, and review some of the theoretical arguments that have been put forward to explain the evolutionary stability of different life cycle strategies. We also describe recent progress in the analysis of the haploid-diploid life cycle of the model angiosperm Arabidopsis thaliana and show how new molecular data are providing a means to test some of the theoretical predictions. Finally, we describe an emerging model organism from the brown algae, Ectocarpus siliculosus, and highlight the potential of this system for the investigation of the mechanisms that regulate complex life cycles.

\section{Introduction}

A wide variety of different life cycles are found in the eukaryotes and one of the challenges of biology is to understand how this diversity has evolved and how (and to what degree) each type of life cycle is stably maintained on an evolutionary timescale. This review will present an overview of life cycle diversity in the eukaryotes along with some of the theoretical models and hypotheses that have been proposed to explain the existence of the different types of life cycle and recent experimental work aimed at testing these hypotheses. In 1998, when Mable and Otto reviewed the current state of theoretical and experimental work aimed at explaining the variety of life cycles among eukaryotes, they concluded that the major 
important evolutionary question of the maintenance of alternation of generations with substantial development in both haploid and diploid phases remained unanswered. We will focus particularly on this problem and discuss how approaches based on the use of model organisms are being developed to address it. A number of other reviews that address several of the topics discussed here in more detail have been published recently (McCormick, 2004; Wilson and Yang, 2004; Yadegari and Drews, 2004; Zeyl, 2004; Boavida et al., 2005; Maraschin et al., 2005), including a recent discussion of the increasing attention that is being paid to ecological and evolutionary aspects of haploid-diploid life cycles (Thornber, 2006). Definitions of some of the terms used in the review are given in Table 1.

\section{Life cycles of the eukaryotes}

Sexual life cycles in the eukaryotes involve a cyclic alternation between diploid and haploid phases with meiosis mediating the transition from the diploid to the haploid state and cell fusion (syngamy) reconstituting a diploid genome. The wide variety of sexual life cycles found in nature share this common structure but exhibit differences in, essentially, two parameters: the temporal importance of each phase (i.e. the proportion of the time spent in the haploid or diploid phase) and the degree of mitotic activity in each phase (clonal multiplication of haploid and/or diploid cells). For the multicellular organisms that will be considered in this review, this mitotic activity not only serves a direct reproductive function, but is also required to construct the multicellular organism itself (somatic development).

Although reproduction is often linked with sex (in most animals for example) this is not always the case and asexual cycles (involving spore formation and/or either vegetative reproduction in plants or fission and fragmentation of the body in animals) can exist either 
instead of, or in addition to, a sexual cycle. Asexual cycles produce a succession of genetically identical individuals with the same level of ploidy.

Three basic types of sexual life cycle are found in eukaryotes: diploid, haploid and haploiddiploid (Figure 1). These cycles differ with regard to the relative position of meiosis and syngamy. When syngamy directly follows meiosis, somatic development occurs only in the diploid generation and the gametes are the only haploid cells. This is called a diploid (or diplontic) life cycle. Conversely, in a haploid (or haplontic) life cycle, meiosis directly follows syngamy and somatic development occurs in the haploid generation with the minimal diploid phase corresponding solely to the zygote. Finally when meiosis and syngamy are separated temporally, somatic development can occur in both the haploid and the diploid phases (as seen, for example, in land plants and in some seaweeds) and the life cycle is termed haploid-diploid (or haplo-diplontic). The two generations of a haploid-diploid cycle can either be dependent (with one generation growing on the other) or independent. The alternation between two distinct types of individual observed in haploid-diploid cycles (corresponding to the gametophytic and the sporophytic generations) has been called a Hofmeister-Strasburger alternation of generations (Bell, 1994).

It should be noted here that the correspondence between ploidy and the sporophyte and gametophyte generations of the life cycle is not absolute. This is clear from a very simple and familiar example for flowering plant biologists in as far as it is the gametophyte stage that is diploid in tetraploid variants of flowering plant species (Leitch and Bennett, 1997). Moreover, and from a more general point of view, many organisms with haploid-diploid life cycles exhibit the phenomena of apospory (the transition from sporophyte to gametophyte without meiosis) and apogamy (the transition from gametophyte to sporophyte without gamete fusion) 
in which there is a clear uncoupling of cellular mechanisms that affect ploidy and the alternation between the sporophyte and the gametophyte (Bell, 1992).

3. Life cycle complexity in multicellular eukaryotes

The following sections describe the various types of life cycle found in the different eukaryote groups that include complex multicellular organisms, with emphasis on red and brown macroalgae because of the particularly broad variety of life cycles in these groups.

\subsection{Life cycle variety in the opistokonts (animals and fungi)}

Most animals possess a sexual, diploid life cycle, the haploid phase being represented solely by the single-celled gametes. This is not an absolute rule, however, and asexual (diploid) life cycles are commonly found in several groups of metazoans. Moreover, some animal life cycles, such as the haplo-diploid life cycles of some insects, involve the production of haploid organisms via parthenogenesis in addition to diploids. Note that such life cycles are referred to as haplo-diploid to distinguish them from the haploid-diploid cycles described above.

Even when an animal has a strict diploid life cycle, its life cycle may still involve the sequential development of distinct phases that exhibit marked differences in morphology (such as, for example, the larval and the adult stages of a fly's life cycle). This phenomenon was first described by Steenstrup (1845), and is therefore referred to as a Steenstrup alternation of phases to distinguish it from the Hofmeister-Strasburger alternation of generations in haploid-diploid life cycles, described above (Bell, 1994). Thus, adoption of a 
haploid-diploid life cycle is not the only way to evolve morphological dimorphism within a life cycle.

Fungal life cycles are very diverse. In general, multicellular development does not occur during the diploid phase (with the exception of some groups such as certain chytrids, which exhibit an alternation between simple, filamentous gametophytes and sporophytes). However, there is often a delay between syngamy and karyogamy (nuclear fusion), resulting in an additional, "dikaryon" phase during which there is a proliferation of cells with two unfused, haploid nuclei. This feature, which is found only in the fungi, adds a further complication to life cycles in this group (Raper and Flexer, 1970). Moreover, the dikaryon phase can be an important phase of the life cycle, both in terms of duration and developmental complexity (for example in the Basidiomycetes).

\subsection{Life cycle variety in the viridiplantae (embryophyte plants and green algae)}

Flowering plants have haploid-diploid life cycles with a highly reduced gametophyte generation corresponding to the pollen grain (consisting of only two or three cells) on the male side and the embryo sac (most commonly consisting of only seven cells) on the female side. The reduction of the gametophyte generation in flowering plants appears to be a derived feature because there is a tendency in other members of the green lineage, in particular in the bryophytes, for the gametophyte generation to be more complex.

In pteridophytes (ferns) the sporophyte generation is generally also the dominant generation but the gametophyte has a considerable level of complexity including features such as cell differentiation, photomorphogenesis and hormone and pheromone responses (Banks, 1999). 
Moreover, in some members of this group that are under unusual selection pressures, the gametophyte appears to have acquired an even greater importance, with some species being driven towards complete reliance on this generation of the life cycle (Watkins and Farrar, 2005).

The tendency towards dominance of the gametophyte is more marked in the bryophytes (e.g. mosses), which diverged from flowering plants more than 400 million years ago. Members of this group possess a gametophyte-dominant life cycle in which the sporophyte grows "parasitically" on the gametophyte.

Work on the evolution of plant life cycles has a long history, the alternation of generations during the life cycles of Bryophyta and Pteridophyta was described in 1851 (Hofmeister, 1851) and the cycles were shown to be haploid-diploid in 1894 (Strasburger, 1894). Interestingly, botanists of this period noted a correlation between habitat and life cycle: most terrestrial plants having a well developed diploid generation, while in aquatic environments the haploid generation was often dominant (Bower, 1908). In the lineage leading to flowering plants, therefore, dominance of the diploid generation seems to be correlated both with the move to drier terrestrial environments and with increased developmental complexity. Bower (1908) suggested that the gametophyte generation was reduced in the terrestrial environment because the motile sperm required an aqueous environment for fertilisation to take place. Two principal theories have been proposed to explain the evolution of the dimorphic alternation of generations in land plants (Lang, 1909) and this question of the origin of land plants and the characteristics of their charophycean ancestors is still debated (Bennici, 2005; Blackwell, 2003; Qui et al., 2006; Taylor et al., 2005). The antithetic theory proposed by Bower (1908) suggests that the sporophyte generation evolved from a haploid green alga with the zygote 
retained in the thallus that gave rise to the diploid phase (sporophyte). The homologous theory assumes a green algal ancestor but with an isomorphic haploid-diploid life cycle.

The Viridiplantae is composed of two main taxa, Streptophyta, which includes the embryophytes (land plants) and several taxa of green algae, and Chlorophyta, which includes the Ulvophyceae. With the exception of the embryophytes, all of the species within the Streptophya have haploid life cycles. This supports the Antithetic Hypothesis, which suggests that the multicellular diploid phase of the embryophyte life cycle evolved via a delay in zygotic meiosis and the insertion of mitotic cell divisions (Kenrick and Crane, 1997; Blackwell, 2003; Qui et al., 2006). The Ulvophyceae are thought to have evolved multicellularity independently of the lineage that led to the embryophytes, Life cycles in this group are variable and can be haploid or haploid-diploid, and iso- or heteromorphic (de Reviers, 2002).

Interestingly, when microspores from many flowering plant species are subjected to a stress treatment, this can induce a switch from the gametophyte to the sporophyte program of development, a type of apogamy called androgenesis (Maraschin et al., 2005). The nature of the stress treatment required to induce this phenomenon depends on the species and the variety under study. It is thought that the applied stress induces dedifferentiation of the developing microspore, allowing the subsequent initiation of a sporophyte developmental program. Apospory (sporophyte to gametophyte transition without meiosis) occurs in a number of apomictic flowering plants (Nogler et al., 1984). Apogamy and apospory have also been observed in many homosporous plants (ferns and mosses; Bell, 1992).

\subsection{Life cycles of the red algae}


Sexuality is not known in unicellular red algae (however, see Yoon et al., 2006 for evidence of genetic recombination in Galdieria) but the multicellular members of this group exhibit several different types of sexual life cycle. Members of the Bangiophyceae, such as the edible seaweed Porphyra, have two morphologically distinct generations with different ploidy levels. The diploid sporophyte (referred to as the conchocelis generation because it was regarded as a different species before the characterisation of the life cycle) is microscopic, creeping and filamentous. Meiosis occurs during germination of the spores, the tetrads together forming the gametophyte thallus, hence the macroscopic gametophytes may be genetically heterogeneous (Ohme and Miura, 1988; Mitman and van der Meer, 1994). They reproduce either directly by asexual mito-spores (so-called monospores), or sexually via gametes, which may be either female macrogametes (oocytes, referred to as carpogonia) or male microgametes (spermatia). Syngamy (fertilisation) occurs while the female gametes are still retained on the gametophyte (Hawkes, 1990). Zygotes divide a number of times and form diploid mito-spores (referred to as "conchospores") that are released to develop into the sporophyte and thus complete the cycle.

The second large group of multicellular red algae, the Florideophyceae, contains the majority of large red algae including economically important agarophytes (Gracilaria, Gelidium) and carragheenophytes (Chondrus, Eucheuma). Most members of this group have a "Polysiphonia-type" life cycle (van den Hoek et al., 1995; de Reviers, 2002). Fertilization occurs on the female individual and involves complex cytological events, resulting in the formation of a cystocarp on the female. The cystocarp releases numerous diploid mito-spores that develop into independent diploid individuals, referred to as the tetrasporophyte. Meiosis occurs during this generation, the resulting meiospores being released to re-establish the 
gametophyte generation. This life cycle is referred to as "triphasic" because the cystocarp may be regarded as a sporophyte generation growing parasitically on the gametophyte. However, it is similar to a diphasic haploid-diploid life cycle, except that the cystocarp is thought to serve to amplify zygotes, a process that may be made necessary by inefficient fertilisation due to the fact that gametes (and indeed also spores) are non-flagellated in the red algae (Searles, 1978).

Deviations from this "Polysiphonia-type" life cycle are manifold and include either loss of sexual reproduction and alternation of generations, or conservation of sexuality but size reduction or suppression of the independence of generations (for reviews see Guiry, 1987; West et al., 2001)

One particularly interesting feature, found in both red and brown macroalgae is the so-called "mixed-phase" phenomenon of individuals that exhibit both sporophyte and gametophyte features in the same generation. Thalli producing tetrasporangia in addition to gametes have been observed in various florideophycean red algae (e.g. van der Meer and Todd, 1977; Destombe et al., 1989; Uwai and Masuda, 1999). In Griffithsia, such thalli were shown to be haploid illustrating that expression of tetrasporophytic features does not require diploidy (Lee et al., 1995).

The original life history of the red algae appears to have consisted of two isomorphic generations, with the cystocarp evolving shortly after the divergence of the Florideophyceae. The primitive lineages of red algae and the Bangiophyta do not seem to have ever possessed a cystocarp. 


\subsection{Life cycles of the brown algae}

As a result of the recent establishment of a robust phylogeny for the brown seaweeds (Phaeophyceae; Draisma et al., 2003; Kawai et al., 2007), it has become clear that the ancestral life cycle in this group consisted of two isomorphic generations. This life history is still found in early branching lineages such as the Ishigeales, the Dictyotales, and the Sphacelariales (Cho et al., 2004) and deviations from this cycle, which involve reduction or suppression of one of the two generations, have occurred in the more recently branched lineages. In most of these variant cycles, the gametophyte is reduced and morphologically simplified but still develops independently of the sporophyte, as for example in the Laminariales which include the largest alga in the world, Macrocystis. However, this reduction appears to have evolved independently in different lineages. In extreme cases, such as the Fucales and Ascoseira, a second generation is absent due to a strong reduction of the gametophyte rendering the life history essentially diplontic and reminiscent of those of the metazoa.

The order Ectocarpales consists principally of small, ephemeral brown algae. This group exhibits a remarkably wide range of different haploid-diploid life cycles. These include cycles in which the two generations can be isomorphic (family Acinetosporaceae), slightly heteromorphic (Ectocarpaceae) or strongly heteromorphic with either the gametophyte (Chordariaceae, Adenocystaceae) or the sporophyte (Scytosiphonaceae) being microscopic (Peters and Ramírez, 2001). Moreover, as an added complication, both generations may be capable of direct, asexual replication (e.g. Myriotrichia, Peters et al., 2004). In addition to the meio-spores that give rise to the gametophyte, the sporophyte may produce mito-spores that appear to invariably replicate the sporophyte via an asexual cycle. Similarly, although the 
gametes produced by gametophytes are capable of fusing to produce sporophytes via syngamy, they can also function as asexual propagules by developing parthenogenetically. This parthenogenetic development can either give rise to a new generation of gametophytes (e.g. Myriotrichia) or can produce parthenogenetic sporophytes (e.g. Ectocarpus; Figure 2), depending on the species. This large variability of life cycles within the Ectocarpales suggests they may be good models to study the genetic regulation of their life histories and to test theoretical predictions about life cycle evolution.

In brown algae, there seems to have been only a single observation of mixed-phase thalli. Kornmann (1956) observed an Ectocarpus in which gametophytes developed vegetatively on parthenogenetic sporophytes (see below for the description of the Ectocarpus life history).

\subsection{General life cycle trends in the eukaryotes}

One general conclusion that can be drawn from the distribution of the three basic types of life cycle (haploid, diploid and haploid-diploid) among eukaryote taxa is that organisms with a high level of structural complexity tend to have a diploid life cycle or at least a dominant diploid generation. The most complex organisms (seed plants and multicellular animals) show diploid dominance whilst many simple organisms (many unicellular protists for example) have haploid or haploid-diploid life cycles. This trend is found on a large scale (among phyla) and is especially clear in plants, where there is a progressive decrease in the size of the haploid generation of the life cycle, relative to the diploid generation, from Bryophyta to Pteridophyta and finally to seed plants. In other taxa such as the red and brown macroalgae the situation is less clear. In algae, the persistence of both generations suggests that haploiddiploidy is remarkably stable, rather than being a transitional state (Klinger, 1993). There are 
some identifiable trends such as the emergence of "Polysiphonia-type" (triphasic) life cycles in the most highly evolved red algal species and the basal nature of haploid-diploid life cycles in the brown algae, and in the latter group there appears also to be a trend towards a reduction of the haploid generation but this is not as marked as in the green lineage (Clayton, 1988; Bell, 1997).

4. Theoretical hypotheses about the evolution of different types of life cycle

Because diploidy is often associated with "biological success" in the sense of attaining complex multicellularity, many arguments have been advanced to explain the evolution of a prolonged diploid phase. However, hypotheses that only predict an adaptive benefit to diploidy are powerless to satisfactorily elucidate the evolution and persistence of haploid and haploid-diploid life cycles. As a result, attention has turned to understanding the maintenance of a diversity of life cycles (Valero et al., 1992; Mable and Otto, 1998; Hughes and Otto, 1999).

\subsection{Genetical models}

The ploidy level of individuals affects their ability to repair DNA damage, and the distribution of genetic variation within and between individuals, which in turn affects the efficiency of natural selection. Several models have investigated how these effects may influence the evolution of life cycles. 
1. DNA damage. Repair of double strand breaks requires the presence of another intact DNA molecule that can be used as a template. This is possible only in diploids, and should thus favour a longer diploid phase (Michod and Gayley, 1994).

2. Deleterious mutations. Deleterious mutations may occur frequently in multicellular organisms (Lynch et al., 1999). These mutations are often recessive, and are thus masked in diploid individuals (due to the presence of a functional copy of the gene) and this may result in selection for a diploid life cycle (Perrot et al., 1991). However, mutations tend to accumulate more in populations undergoing diploid life cycles (because they are masked). The overall effect of deleterious mutations on life cycle evolution have been studied using "modifier" models, which incorporate one or several loci at which deleterious mutations occur plus a modifier locus affecting the relative durations of the haploid and diploid phases of the life cycle (Otto and Goldstein, 1992, Jenkins and Kirkpatrick, 1995, Otto and Marks, 1996; Hall, 2000). Using such models, one can determine the conditions under which alleles that increase the proportion of the life cycle spent in the haploid (or diploid) phase are selected at the modifier locus. A general result is that diploidy has a "short-term" advantage (due to the masking of recessive deleterious alleles), while haploidy has a "longer-term" advantage, because it allows a better selective elimination of deleterious alleles. Because the advantage of diploidy is short term, it is predicted that evolution towards diploidy should be irreversible. The longer-term advantage of haploidy can overcome the short-term advantage of diploidy, but only if it is confined to individuals with a longer haploid phase, which may be the case when there is little genetic mixing in the population, i.e. little recombination and/or little outcrossing and/or little sexual reproduction (Otto and Goldstein, 1992; Otto and Marks, 1996). One would thus expect to observe haploid life cycles in species where inbreeding, or clonal reproduction, is common but phylogenetic studies have not detected any clear 
correlation between these phenomena (Bell, 1997; Mable and Otto, 1998). Finally, it is important to note that these models cannot explain the maintenance of a haploid-diploid life cycle (they predict evolution towards haploidy or diploidy, depending on the parameter values), but see Richerd et al. (1993) and (1994). In these two last models, the maintenance of a haploid-diploid life cycle is predicted for certain values of haploid to diploid fitness ratio. The advantage of haploid-diploidy is that sex occurs half as often assuming that individual generation times are the same length as in haploid or diploid life cycles. As pointed out by Mable and Otto (1998), the model proposed by Richerd et al. (1994) predicts that haploiddiploidy would then be favoured under conditions in which the cost of sex is high.

3. Advantageous mutations. Similar arguments come into play when considering beneficial mutations. Diploid cells contain twice as many genes, increasing the probability that an advantageous mutation will occur (Paquin and Adams, 1983), or that a deleterious allele that was maintained in the population due to masking becomes advantageous after a change in environment. However, beneficial alleles are immediately expressed in haploids, whilst they are masked in diploids until they occur in the homozygous state, and thus have a greater chance of being lost from the population when rare, due to random events. As a consequence, one finds that diploidy is favoured over haploidy if beneficial mutations tend to be dominant, and if genetic mixing is frequent in the population (Orr and Otto, 1994). At present little is known about the dominance of advantageous mutations.

4. Host-parasite interactions. Nuismer and Otto (2004) recently suggested that host-parasite interactions may favour diploidy in hosts, allowing them to harbour a greater diversity of recognition molecules that may prevent infection (such as antibodies), and haploidy in parasites, in order to express as few antigens as possible. 


\subsection{Ecological models}

Several ecological factors that may influence life cycle evolution have been discussed.

1. The nutrient-saving hypothesis. Lewis (1984) proposed that haploid cells may enjoy an advantage in nutrient-poor environments, because haploid cells are often smaller and have thus a greater surface area to volume ratio, and also because they need less energy to replicate their DNA. This effect may be more relevant for unicellular than for multicellular organisms.

2. Optimal nuclear or cell size. Cavalier-Smith (1978) presented a similar type of hypothesis, suggesting that the evolution of ploidy levels may be a by-product of selection for optimal nuclear or cell size: conditions favouring smaller individuals would select for haploid life cycles, while conditions favouring larger individuals would favour diploid cycles.

3. Difference in ecological niche between the haploid and diploid phase. Hughes and Otto (1999) constructed a model to explore the hypothesis that haploid-diploid life cycles may be favoured when organisms exploit their environment more efficiently through niche differentiation of the two ploidy phases (Stebbins and Hill, 1980; Willson, 1981). They indeed found that haploid-diploid life cycles could be selected for under a broad range of conditions when the haploid and diploid individuals presented ecological differences. One can argue that there are different ways of evolving towards an alternation of morphs that do not necessarily imply changes in ploidy (as in the alternation of larval and adult phases that occurs in many animals). However, it may be easier to evolve different morphologies starting from different ploidy phases. 


\subsection{Sporophytic and gametophytic alternation of "form/generation": different properties of spores and gametes}

A very different argument has been advanced in the literature to explain the general evolutionary trend in vascular plants towards an increase in size of the diploid sporophyte and a concomitant reduction of the haploid gametophyte. In comparison with previous hypotheses, this argument is mainly based on the different properties of spores and gametes and not on differences between ploidy levels. This argument, first advanced by Bower (1908), was developed more recently by Keddy (1981) and Bell (1997) and relies on the different functions of gametes, which are adapted for fusion, and spores, which are adapted for dispersal. It is proposed that the growth form of the gametophyte evolved towards a reduction in size to favour close proximity, maximising fertilisation by increasing the probability of contact between male and female gametes. On the other hand, sporophytes would have been selected to be large and erect to maximise spore dispersal and hence colonisation success. Bell (1997) emphasizes that, in brown seaweeds (Phaeophyceae), the association of gametophyte and sporophyte with characteristic morphological states is not necessarily regulated by ploidy, as reflected by the very widespread occurrence of haploid sporophytes (see above). He concluded that the classic sexual cycle (when the haploid stage becomes specialised as a gametophyte and the diploid stage as a sporophyte) can be interpreted as evolving from an asexual alternation of small and large individuals through selection for the appropriate association of ploidy with vegetative stage. If this is true we can expect that the genes that mediate sporophyte and gametophyte development would be different from the genes involved in the sexual cycle (meiosis and syngamy). 


\subsection{Empirical support for the above theoretical hypotheses}

Altogether, a considerable number of hypotheses have been generated to explain the range of life cycles found in nature but, in contrast, relatively few experimental studies have been conducted to test these hypotheses (for reviews see Perrot, 1994; Mabble and Otto, 1998; Zeyl, 2004). Most of the experiments that have been carried out have involved comparing the performances of haploids and diploids in relation to both genetic and ecological parameters. These studies have provided empirical support for genetic theories that address masking and/or repair of deleterious mutations. Diploidy has been shown to be advantageous in highly mutagenic environments by comparing haploid or diploid strains of unicellular organisms such as yeast (Waters and Moustacchi, 1975), haploid and diploid juveniles of a red seaweed (Destombe et al., 1993) and artificial haploid and diploid protoplasts of seed plants (Krumbiegel, 1979) or animals (Mezger-Freed, 1974). In addition, experimental studies of the ability to acquire advantageous mutations in haploid and diploid evolving populations have been conducted in order to test hypotheses regarding the evolution of ploidy. Most of this latter work has been done using yeast (Adams and Hansche, 1974; Hansche, 1974; Paquin and Adams, 1983; and more recently Zeyl et al. 2003, Sliva et al. 2004) apart from one study that used a simple, multicellular organism (a filamentous fungus of the genus Aspergillus; Schoustra et al., 2005). The results obtained in these studies were in agreement with the main predictions of the model proposed by Orr and Otto, i.e. that fixation of haploidy or diploidy depends on population size and the dominance of advantageous mutations. However, a very surprising result was published recently by Gerstein et al. (2006) that contrasts with all previous explanations of ploidy evolution (but see Perrot, 1994). Gerstein et al. followed the evolution of haploid, diploid and tetraploid lines of the budding yeast $S$. cerevisiae over 1,800 generations and showed that the haploid and tetraploid lines converged toward diploidy, the 
historical state of S. cerevisiae. They suggest that evolutionary inertia or historical constraint might prevent shifts away from the ploidy level to which an organism has historically adapted. Nevertheless, the frequent observation of life cycle variations in natural environments for a significant number of algal species (see above) suggests that life cycle evolution may be less constrained in some groups.

The major contribution of recent theoretical studies has been their focus on the maintenance of haploid-diploid life cycles (Mabble and Otto, 1998). Thornber (2006) has recently reviewed experimental studies that address the roles of the two generations of a life cycle at the physiological and the ecological level in seaweeds. Theoretically, if the sporophyte and gametophyte exploit different ecological niches this could stabilise a haploid-diploid life cycle, preventing loss of one of the two generations. There is considerable support for this hypothesis in species that have heteromorphic life cycles adapted to environments that differ in terms of temperature, light level and herbivory (Lubchenco and Cubit, 1980; Cunningham et al., 1993). Such an effect may even apply to isomorphic cycles if there are cryptic differences between the two generations (Hughes and Otto, 1999). New information is in agreement with this hypothesis since differences have been reported in isomorphic species in term of dispersal (Destombe et al., 1992), biomechanical properties (Carrington et al., 2001) and chemical defences (Cronin and Hay, 1996; Potin et al., 1999). This has stimulated efforts to understand the ecology of haploid-diploid life cycles not only in terms of functional properties but also in terms of the population dynamics of the two generations. Indeed, recent studies have provided data on parameters such as the haploid/diploid ratio, fertility and survivorship (Destombe et al., 1989; Ang and De Wreede, 1990; Engel et al., 2001; Thornber and Gaines, 2004; Fierst et al., 2005) providing parameter estimates to help test the models proposed by Richerd et al. (1994) and by Hughes and Otto (1999). 
The ecological hypothesis that has received the greatest amount of experimental attention is the nutrient-saving hypothesis of Lewis (1985). The advantage of haploidy for growth in poor environments has been established, not only for unicellular yeast (Adams and Hansche, 1974; Mable, 2001) but also for multicellular organisms (growth of juveniles of the red seaweed Gracilaria: Destombe et al. 1993 and mycelium growth of the fungus Aspergillus: Perrot, 1994).

Clearly, theoretical models and empirical data have demonstrated the importance of obtaining detailed biological descriptions of the two generations of a life cycle in order to understand the mechanisms that have led to the evolution and maintenance of haploid-diploid life histories. Additional information is required not only about the ecology and the physiology of each generation but also about gene expression and function at the molecular level. However, molecular analyses of this type have only been carried out for a limited number of species so far, essentially within the viridiplantae, with the most detailed information now being available for the model angiosperm Arabidopsis thaliana. Genome-scale analyses of gene expression in the male and female gametophyte have recently been carried out for this model organism, complementing the wealth of data already available for the sporophyte generation. The following section summarises some of the results obtained by these studies.

5. Molecular analysis of the male and female gametophytes of flowering plants and comparison with the sporophyte generation

\subsection{The male gametophyte}


Functional analysis of the gametophyte generation of flowering plants is challenging because both the male and female gametophytes develop within the tissues of the sporophyte, often over a short time-span, and in both cases development is dependent on sporophyte functions (reviewed in Weterings and Russell, 2004). The haploid nature of the gametophyte also means that lethal mutations cannot be maintained in a heterozygous context. Sections 5.1 and 5.2 will describe recent advances in the characterisation of flowering plant male and female gametophytes obtained by the application of genomic and genetic approaches.

The principal function of the male gametophyte of flowering plants is to deliver the male gametes to the female gametophyte. This generation of the life cycle can be divided into two parts, the first corresponding to the development of the male gametophyte in the anther (microgametogenesis) and the second corresponding to its transfer to the female part of the flower and the delivery of the sperm cells by the pollen tube to the embryo sac. Male gametophytes are derived from diploid microsporocytes (pollen mother cells) that undergo meiosis to generate a tetrad of haploid microspores. Each microspore subsequently undergoes two mitotic divisions to generate the male gametophyte (the second of these mitotic divisions occurs either during the development of the pollen grain or in the growing pollen tube, depending on the species).

Early work on gene expression in the male gametophyte concentrated on the identification of genes with a pollen-specific pattern of expression. These studies identified both "early" genes, expressed during development, and "late" genes, expressed in mature pollen and during the pollination process (Mascarenhas 1990, McCormick, 2004). The cell-specific expression patterns of some of these genes have been studied and most are expressed specifically in the 
vegetative cell (McCormick, 1993, Taylor and Hepler, 1997). This is consistent with the fact that the chromatin of the sperm cells is condensed, and suggests that the majority of gene expression occurs in the vegetative cell. However, analysis of a maize male sperm cell cDNA library has shown that the sperm cells nonetheless contain a diverse population of mRNAs, many of which are not found in the vegetative cell (Engel et al., 2003). Several of the sperm cell-specific transcripts are already present at the unicellular microspore stage, suggesting that they may be synthesised early and partitioned specifically to the sperm cell following mitosis.

The availability of the complete genome sequence for Arabidopsis has made genome-wide transcriptome analysis possible, providing a much more complete picture of gene expression in the male gametophyte of this species. A number of studies have now been carried out using either microarray or SAGE approaches (Becker et al., 2003; Honys and Twell, 2003; Lee and Lee, 2003; Honys and Twell, 2004; Pina et al., 2005) and although there are significant differences between the results obtained, due to differences in the experimental approaches used, some clear general conclusions can be drawn. Firstly, a large number of genes are expressed in the male gametophyte; Honys and Twell (2004) identified 13,977 male gametophyte-expressed mRNAs (61.9\% of the genes tested were found to be expressed). Of these genes, only $9.7 \%$ were male gametophyte-specific indicating that a large number of genes are expressed during both the gametophyte and the sporophyte generations of the life cycle.

Analysis of different stages of development showed that there is a decline in the complexity of the transcriptome as the male gametophyte matures, particularly at the transition from bicellular to tricellular pollen (Honys and Twell, 2004). This trend was accompanied by an increase in the proportion of male gametophyte-specific transcripts. A number of transcripts 
that are abundant at earlier stages become less abundant, whilst transcripts associated with the cytoskeleton, the cell wall and signalling become over-represented suggesting that these classes of gene play particularly important roles in the mature pollen grain.

Taken together, therefore, these genome-scale transcriptome studies have revealed that the male gametophyte is surprisingly complex at the genetic level, despite having a simple structure at the cellular level. A large number of genes are expressed in the male gametophyte and, although most are also expressed in the sporophyte, a significant number are expressed only in the gametophyte indicating the presence of biological processes specific to this generation of the life cycle.

In addition to these transcriptomic approaches, proteomic analyses of pollen proteins have also been carried out for a number of species, including Arabidopsis, providing a complementary view of gene expression at the protein level (Mayfield et al., 2001; Kerim et al., 2003; Fernando 2005; Holmes-Davis et al., 2005; Noir et al., 2005; Dai et al., 2006).

Genetic approaches, aimed at identifying genes with important functions during male gametophyte development, are producing information that is complementary to that obtained by the transcriptomic approaches described above. Table 2 lists a number of genes with key roles at specific stages of male gametophyte development that have been characterised genetically. This approach is providing essential information about the regulation of male gametophyte-specific functions both during early development and in the mature pollen grain, thereby providing important insights into male gametophyte function. The relevance of these studies to understanding the life cycle will be discussed below. 


\subsection{The female gametophyte}

Analysis of the transcriptome of the female gametophyte is even more challenging than for the male because it is difficult to separate female gametophyte tissue from that of the surrounding sporophyte. Most of the progress in this area has come from the analysis of cDNA libraries constructed from microdissected female gametophyte cells such as the egg cell or the central cell, mainly from monocot species such as maize or wheat (Dresselhaus et al., 1994; Yang et al., 2006; Le et al., 2005; Sprunck et al., 2005). This sort of approach is not possible with Arabidopsis because of the small size of the embryo sac but Yu et al. (2005) were able to identify 225 female gametophyte-expressed genes by a microarray approach that compared wild type ovules with ovules of the $s p l$ mutant in which the embryo sac fails to develop. As expected with a differential screen of this type, expression of a large proportion of the genes identified (45\%) had not been detected previously in any sporophyte tissue. Studies of this kind are providing information about gene expression in the female gametophyte and have identified many genes expressed specifically during this generation of the life cycle. However, at present they fall short of providing the genome-scale view of gene expression that is now available for the male gametophyte of Arabidopsis.

As was the case for the male gametophyte, genetic approaches have provided data that are complementary to those obtained by transcriptome analysis and large number of genes that are required for female gametophyte development have been identified in Arabidopsis (Table 2). Most of the mutants that do not show lesions on the surrounding sporophytic tissue, fall into phenotypic categories corresponding to key developmental events such as mitosis, nuclear fusion, cellularisation and cell death (Drews and Yadegari, 2002). A recent, highthroughput screen of Ds transposon insertion lines has made a significant contribution to the 
list of female gametophyte mutants, identifying 130 genes with this phenotype in Arabidopsis (Pagnussat et al., 2005). Nearly half of these mutants were primarily defective in post fertilization processes depending on the maternal allele, suggesting that genes expressed in the female gametophyte or the maternal genome play a major role in the early development of plant embryos.

\subsection{How do these molecular analyses help us understand haploid-diploid life cycles?}

The principal aim of the studies described above is to obtain a deeper understanding of the biological function of the gametophyte during the plant life cycle. Differential expression studies and tissue- and cell-specific cDNA libraries are identifying genes involved in functions that are specific to each generation. In addition, mutant analyses are identifying genes that regulate specific aspects of gametophyte or sporophyte biology or that are essential for the implementation of the gametophyte or the sporophyte developmental programs. This is important because understanding the biology of the two generations of the life cycle is an essential requisite for understanding the life cycle itself. Such studies can provide important clues as to why the two different generations have been maintained. Clearly, for angiosperms, both the male and the female gametophyte play important roles in reproduction. The habitats of terrestrial plants pose specific problems because the sporophyte stage is immobile and, in many cases (particularly within the angiosperms), non-flagellated gametes must be transferred between plants (or at least between male and female organs) via a hostile, non-aqueous environment. In such species, the pollen grain has important functions in the dispersal and protection of the male sperm cells and also provides the structure (the pollen tube) that delivers the sperm cells to the female gametophyte (McCormick, 2004). The female gametophyte, on the other hand, plays an important role in attracting the pollen tube and by 
providing the cellular environment in which the double fertilisation that leads to the production of two "organisms", the embryo and the endosperm, takes place (Drews and Yadegari, 2002). The female gametophyte also has a significant influence on the early development of the sporophyte generation. The grouping of pairs of gametes together within the gametophytes provides a means to coordinate double fertilisation and this may have been a factor that contributed the maintenance of the gametophyte generation in flowering plants. Transcriptome analyses have demonstrated that large numbers of genes are expressed during the gametophyte generation of the life cycle highlighting the importance of this generation in flowering plants, despite its reduced size and complexity. Moreover, significant numbers of genes are expressed specifically in both the male and the female gametophyte indicating specific functions, distinct from those carried out by the sporophyte generation.

It should be noted, however, that these studies have also shown that a large number of genes are nonetheless expressed during both the gametophyte and sporophyte generations. From a theoretical point of view, this phenomenon of "gene sharing" between gametophyte and sporophyte generations is likely to be important because purifying selection, occurring during the haploid gametophyte phase, can eliminate deleterious mutations from those genes, increasing the fitness of the sporophyte generation. Mulcahy (1979) suggested that the closed carpel of angiosperms, particularly when combined with insect pollination (which allows the transfer of large masses of pollen), creates an ideal environment for natural selection to eliminate sub-optimal haploid genomes that reduce the metabolic vigour of pollen grains, compromising their ability to compete with other pollen grains to pollinate an ovule. Selection can potentially act very efficiently during the gametophyte generation because of the large population sizes (of pollen grains) and because the haploid genome allows the genotype to be directly reflected in the phenotype. Several studies have shown that gametophytic selection 
can influence the sporophyte generation (i.e. that applying a selection pressure during pollination results in improved growth during the subsequent sporophyte generation, e.g. Mulcahy and Mulcahy, 1975) and the extensive overlap between the sets of genes expressed in the Arabidopsis sporophyte and gametophyte generations (identified by the expression experiments described above) provides a genetic basis for this. Moreover, these transcriptomic approaches allow a measurement of the extent of the overlap between the two sets of genes expressed in the sporophyte and the gametophyte, allowing a more accurate quantification of the potential effect of purifying selection during the haploid phase on the fitness of the sporophyte. This sort of information could now be integrated into theoretical models.

Interestingly, a recent study by Seoighe et al. (2005) showed that pollen-specific genes in Arabidopsis have significantly shorter introns than genes expressed in the sporophyte and the authors suggest that this is because they are under a specific selection pressure to reduce the cost of transcription by reducing the size of the transcription unit. A similar, but weaker and less consistent, trend was observed for all the pollen expressed genes (ie. including those also expressed in the sporophyte) compared to genes expressed exclusively in the sporophyte. This study provided the first report of a molecular signature of strong gametophytic selection and provides further support for the potential importance of selection during the gametophyte generation.

The availability of detailed information about the genes that are expressed during each generation of the life cycle opens up the possibility of carrying out further analyses of this type in the future, using structural and compositional analyses of these genes to test models of life cycle evolution. For example, as appropriate information on gene polymorphism becomes 
available, ratios of non-synonymous to synonymous mutations could be determined for the set of gametophyte-specific genes and compared with the corresponding ratios for the sporophyte-specific gene set to detect and quantify selection pressures during the two generations of the life cycle. In the longer term, it will be interesting to determine the extent of "gene sharing" between the sporophyte and gametophyte in a range of organisms with haploid-diploid life cycles in order to correlate this genetic factor with other life cycle parameters such as whether the life cycle is heteromorphic or isomorphic or whether the two generations are dependent or independent.

Molecular analyses are clearly providing new insights into the biology of the gametophyte and sporophyte generations of the life cycle and the selective pressures acting on these generations. Are they also providing information about the regulation of the life cycle? Mutations in several of the genes listed in Table 2 result in arrest at crucial stages of the transition from the sporophyte to the gametophyte generation and these genes could therefore be considered as candidate regulatory genes. Similarly, genes that are essential for fertilisation or for the initiation of embryo development (acting at the transition from the gametophyte to the sporophyte generation) are also candidate regulators of the life cycle (Berleth and Chatfield, 2002). Care must be taken in assigning a regulatory role to these genes, however, because the observed phenotypes may have other explanations. For example, the transition from the diploid to the haploid state during meiosis can result in the unmasking of deleterious mutations with the result that mutations affecting essential, general ("housekeeping") cell functions can cause a specific arrest at this stage. Similarly, embryo lethal mutations may cause early arrest by affecting "housekeeping" functions that are necessary throughout the sporophyte stage but which do not occur, or are mediated by different genes, during the gametophyte stage (Gallois, 2001). In other cases, the effect of a mutation may be indirect, for 
example many mutations that cause early arrest of male gametophyte development (Wilson et al., 2001; Canales et al., 2002; Zhao et al., 2002; Yang et al., 2003; Albrecht et al., 2005; Colcombet et al. 2005; Vizcay-Barrena et al., 2006) also affect development of the tapetum (the cell layer that surrounds the developing microspores in the anther) and their effect on gametophyte development may, therefore, be indirect, as male gametophyte development is known to be highly dependent on the presence of a functional tapetum. Even when a mutation affects a gene that has a specific function during a key stage of the life cycle, the gene may be a downstream effector rather than a regulatory gene (although, the distinction between these two classes may sometimes be difficult, for example when an effector is also a key integrator of several regulatory signals). This is probably the case for many of the genes with specific roles during meiosis (Caryl et al., 2003).

One strong candidate for a life cycle regulatory gene is the Arabidopsis SPOROCYTELESS $(S P L)$ gene. $S P L$ is essential for the differentiation of sporocytes (which normally subsequently undergo meiotic divisions to form microspores and megaspores; Yang et al., 1999). On the female side, ovule primordia of $s p l$ mutants possess an enlarged hypodermal cell but this does not differentiate into a megasporocyte and meiosis does not occur. Similarly, on the male side, primary sporogenous cells fail to differentiate into microsporocytes. The tapetum also fails to develop but this is probably an indirect effect of the loss of sporocyte differentiation. SPL is a novel nuclear protein related to MADS box transcription factors. This is consistent with the proposition that it acts as a transcriptional regulator of sporocyte development (Yang et al., 1999).

The Arabidopsis AGP18 gene is expressed very specifically in the megaspore mother cell, in the four meiotically-derived megaspores and in the adjacent nucellar cells. RNA interference- 
induced posttrancriptional silencing of this gene resulted in the arrest of female gametophyte development at the one-cell, megaspore stage suggesting that this gene may have a very specific function during the initiation of the developmental program of the female gametophyte (Acosta-Garcia and Vielle-Calzada, 2004).

Ovules of Arabidopsis DYAD/SWITCH1 mutants contain a pair of large cells in the place of an embryosac (Siddiqi et al., 2000). At first view this phenotype could be interpreted as representing a switch from a meiotic to a mitotic division of the megaspore mother cell or, in other words, a switch from a haploid (gametophyte) to a diploid (sporophyte?) developmental program. However, detailed analysis of this mutant revealed that the two cells are actually the product of a defective meiotic division indicating that $D Y A D / S W I T C H 1$ 's effect on life cycle progression is mediated via an essential role during meiosis (Siddiqi et al., 2000, Mercier et al., 2003). This example clearly demonstrates the importance of careful analysis of mutant phenotypes when interpreting the effects of mutations that modify crucial steps of the life cycle.

Ectopic expression of several genes (BABY BOOM, SERK, LEC1 and LEC2) has been shown to promote embryo formation suggesting that they may play important roles in the initiation of the sporophyte developmental program (Boutilier et al., 2002; Schmidt et al., 1997; Lotan et al., 1998; Stone et al., 2001). Moreover, the Brassica napus homologue of BABY BOOM (Boutilier et al., 2002) and the maize homologue of SERK (ZmSERK1; Baudino et al., 2001) are both expressed during microspore embryogenesis (androgenesis) where there is a transition from a gametophyte to a sporophyte pattern of development. It should be noted, however, that all four genes have a very broad pattern of expression (even if expression levels are usually higher in reproductive organs) and they may therefore act downstream of the 
mechanism that controls the switch from gametophyte to sporophyte development.

Epigenetic modifications of chromatin have been shown to play important roles at many transition points during the life cycles of both plants and animals (Guitton and Berger, 2005a). In Arabidopsis, the FIE-MEA polycomb complex, which includes MEDEA (MEA), FERTILISATION INDEPENDENT ENDOSPERM $\quad$ (FIE), $\quad$ FERTILISATION INDEPENDENT SEED 2 (FIS2) and MULTICOPY SUPPRESSOR OF IRA 1 (MSI1), plays a key role at the transition between the gametophyte and sporophyte generations. Mutation of the genes encoding these proteins has been shown to lead to the initiation of sporophyte development resulting in the proliferation of a diploid endosperm and, in some instances, formation of an embryo-like structure from the egg cell (Chaudhury et al., 1997; Guitton and Berger, 2005b).

A number of candidate life cycle regulatory genes have therefore been identified for both the gametophyte and the sporophyte generations but these studies have not yet provided a clear picture of the regulatory pathways involved. Evolutionary models could make a useful contribution to the efforts to dissect these regulatory pathways. For example, as discussed above, it has been proposed that haploid-diploid life cycles arose in the green lineage by a two-step process in which meiosis and syngamy were synchronised with a pre-existing, asexual cycle that involved an alternation between small and large individuals (Bell, 1992). If this was the case then we might expect the regulatory pathways that control sporophyte/gametophyte alternation to be different to those that control meiosis and syngamy (with cross-regulation occurring between the two pathways). The model therefore provides a conceptual framework for the interpretation of experimental data and suggests testable hypotheses about the system. 
6. New approaches for identifying genes that regulate progression through the life cycle

\subsection{Limitations of current model organisms}

Molecular approaches are proving to be an effective means to investigate the biological functions of the two generations of haploid-diploid life cycles, at least in model organisms such as Arabidopsis. They have also allowed the identification of a small number of genes that are essential for crucial steps in the life cycle such as sporocyte development and meiosis. However, for the multicellular organisms that are the subject of this review, perhaps the most interesting regulatory mechanisms are those that coordinate the sporophyte and gametophyte developmental programs with the alternation between meiosis and syngamy during the life cycle, and little progress has been made in this area.

We do not understand, for example, how organisms with haploid-diploid life cycles assure that the appropriate program of multicellular development (sporophyte or gametophyte) is deployed at the appropriate stage of the life cycle. Presumably, regulatory mechanisms exist that detect key events in the life cycle, such as meiosis and syngamy, and initiate the appropriate developmental program in response to these events. Characterisation of such regulatory mechanisms would be a crucial step towards understanding the evolution and function of haploid-diploid life cycles. Factors that influence the structure of the life cycle are expected to act via such regulatory mechanisms. Access to the corresponding genes would, therefore, allow the effects of factors such as seasonal changes or stresses to be assessed at the 
molecular level providing essential clues to the function of the different generations of the life cycle.

From a practical point of view, however, identification of genes that coordinate sporophyte/gametophyte development with life cycle progression may be difficult because mutations in such genes might be expected to lead to gametophyte or embryo lethality. Mutations in this class of life cycle regulatory gene would therefore be difficult to distinguish from mutations in downstream genes that are essential for the progression of early events in the sporophyte and gametophyte developmental programs. In theory, however, a mutation in a gene that regulates the transition between two generations of a life cycle could also lead to the development of the "wrong" generation at one of the transition points in the life cycle, a gametophyte where a sporophyte would be expected for example. This would be analogous to a homeotic conversion at the tissue and organ level, although in this case occurring at the level of an individual organism. It could be argued that such a phenotype would be unlikely because of the difference in ploidy between the two generations but, as discussed above, the relationship between ploidy and the alternation of generations during the life cycle is not absolute. Redirection from a gametophyte to a sporophyte developmental program clearly occurs during androgenesis and gynogenesis in flowering plants but the regulatory mechanisms that control these processes have not yet proved to be accessible genetically. This may be because early development of both the gametophyte and the sporophyte occurs within the tissues of the parental generation, with the parent having an important influence on the development of the next generation of the life cycle, at least during the early stages. In such a situation, where multiple regulatory inputs both from within and from outside the gametophyte or sporophyte are necessary for normal developmental progression (or even if these external influences tend only to maintain the original state), mutants in which there is a 
switch from one generation to the other would be very difficult to obtain.

Are there alternative model systems in which it might be easier to identify life cycle regulatory genes? Mosses are potentially interesting organisms for this type of study because both the sporophyte and the gametophyte exhibit a certain amount of developmental complexity. Mosses also possess most of the developmental patterning genes found in flowering plants (Floyd and Bowman, 2007). Many of these genes are expressed during the gametophyte generation (Nishiyama et al., 2003) and it has been proposed that gametophyte genes have been co-opted for the sporophyte developmental program during the evolution of land plants. Homologous recombination in the model moss Physcomitrella patens represents a powerful tool to explore gene function, particularly when combined with recently developed genomic tools including the complete genome sequence, large numbers of ESTs, and RNAinterference methodology (Quatrano et al., 2007). However, the development of the sporophyte in mosses is likely to be considerably influenced by the gametophyte generation because the former generation grows "parasitically" on the latter (although this is obviously also a problem in Arabidopsis, where it is the gametophyte generation that is dependant on the sporophyte generation). Moreover, classical genetic approaches involving crosses are technically difficult in P. patens, limiting the scope for forward genetic approaches. However, this latter limitation will be alleviated by the growing potential for high-throughput approaches based on the genome sequence.

Another potentially interesting model organism is the fern Ceratopteris (Hickok et al., 1995; Banks, 1999). Ferns also represent potentially interesting models to study the alternation of generations in haploid-diploid life cycles because they possess a multicellular gametophyte with differentiated cells and a specific developmental pattern together with a morphologically 
complex sporophyte. Apospory can be induced in Ceratopteris (DeYoung et al., 1997), indicating that gametophyte/sporophyte alternation can be uncoupled from ploidy, but no mutants that affect the switch between the two generations of the life cycle have been reported so far in this system.

The diversity of the life cycles of brown and red macroalgae also makes them obvious candidates for the study of life cycle regulation but the lack of well-developed model organisms in these groups has hitherto limited the scope for investigating these systems on a molecular level. This situation is currently changing and model organisms are emerging for both the red and the brown macroalgae. For the red algae, interest is being focused on Porphyra yezoensis (Waaland et al., 2004; Kitade et al., 2004), whilst Ectocarpus siliculosus has been proposed as a model organism for the brown algae (Peters et al., 2004). Ectocarpus is particularly interesting because it's life cycle involves an alternation between morphologically similar sporophyte and gametophyte generations, both of which develop independently of the parent organism from a single progenitor cell that is released into the sea water environment. Moreover, both haploid sporophyte and diploid gametophyte variants have been described in Ectocarpus indicating a weak relationship between life cycle generation and ploidy in this organism (Müller, 1967; Figure 2). Ectocarpus, therefore, represents a promising system to search for mutations that affect the switch between the sporophyte and gametophyte generations.

The following section will provide an overview of the current efforts to develop Ectocarpus as a model organism and the subsequent section will then describe the life cycle of Ectocarpus in more detail and the approaches being used to investigate its regulation at the molecular level. 
6.2. Emergence of Ectocarpus siliculosus as a general model organism for the brown algae

Experimental work on Ectocarpus dates back to the beginning of the 19th century (Berthold, 1881) but it was principally the work of Dieter Müller's group in Konstanz, Germany over the last 4 decades that has led to the emergence of this organism as a laboratory model (Müller, 1967, 1976; Müller et al., 1971, 1990; Bräutigam et al., 1995; Delaroque et al., 2001). Ectocarpus has a number of features that make it well adapted as a laboratory organism. It can be grown in nutrient-enriched seawater in Petri dishes and the life cycle can be completed in the laboratory in a period of about 3 months (Müller et al., 1998; Peters et al., 2004). In culture, this alga usually becomes mature and fertile at a size of one to two centimetres (although thalli are often considerably larger in the field) making it easy to handle large numbers of organisms. Ectocarpus is highly fertile, producing large numbers of several different types of zoids, and controlled crosses can be carried out, allowing classical genetic methods to be used. Moreover, the Ectocarpus genome is relatively small (approximately 200 Mbp) compared to other model brown algae such as Fucus serratus or Laminaria digitata (1095 and 640 Mbp respectively; Peters et al., 2004).

Based on these features, we have recently proposed Ectocarpus as a general model organism for the brown algae with the aim of making genomic tools and gene function analysis available for this species (Peters et al., 2004). The genome of Ectocarpus is being sequenced as part of this project (http://www.cns.fr/externe/English/Projets/Projet_KY/organisme_KY.html) and genetic screens for a range of different types of mutant, including life cycle mutants, have been, and are being, carried out. 


\subsection{Ectocarpus siliculosus: a model haploid-diploid life cycle}

The sexual part of the life cycle of Ectocarpus involves an alternation between a diploid sporophyte and haploid, dioecious (male and female) gametophytes (Figure 2). Sporophytes and gametophytes have a similar morphology, both consisting of branched, uniserate filaments, so that it can be difficult to distinguish between sporophytes and gametophytes in the field. In culture, however, sporophytes form fairly compact thalli that are firmly attached to the substratum whilst gametophytes have a more feathery appearance and are less strongly attached, tending to float off into the medium.

Haploid gametophytes produce plurilocular gametangia containing either male or female gametes of identical size (morphological isogamy). Zygotes formed from the fusion of a male and a female gamete develop into diploid sporophytes which, in turn, produce the meiospores that will develop to form the next gametophyte generation. Meiospores are produced in unilocular sporangia in which a single meiosis, followed by several mitotic divisions, gives rise to about 100 spores.

In addition to this sexual cycle, Ectocarpus can also reproduce asexually in a number of different ways. The simplest of these is via the production of mito-spores by the sporophyte (in plurilocular sporangia that are morphologically similar to the plurilocular gametangia of the gametophyte). These mito-spores represent a means of clonally multiplying the sporophyte generation. A second, particularly interesting mode of asexual reproduction is the parthenogenetic development of unfertilised gametes (i.e. gametes that have not encountered a gamete of the other sex) into sporophytes. Estimates of ploidy based on chromosome counts 
indicate that in most cases these parthenosporophytes are haploid (Müller, 1967). The concept of a haploid sporophyte can be confusing but these organisms are clearly functional sporophytes; the zoids produced in their plurilocular zoidangia are mito-spores and not gametes because they are unable to fuse with gametes of the opposite sex to produce zygotes. Moreover, the parthenosporophytes produce unilocular sporangia, structures that are only found in the sporophyte generation.

The reason these parthenosporophytes are interesting is because they indicate that the "choice" to deploy the gametophyte or the sporophyte developmental program is not determined by the ploidy of the initial cell but rather is under some sort of genetic or epigenetic control. Preliminary data from mutant analyses support this interpretation. Two single-locus mutations have recently been isolated that cause partial and complete conversion, respectively, of the sporophyte generation into a gametophyte (unpublished data). Future exploitation of this type of mutant in Ectocarpus is expected to provide access to the regulatory mechanisms that control the switch between the two generations of the life cycle. An understanding of these mechanisms would bring us one step closer to solving the perennial mystery of the evolution and stable maintenance of haploid-diploid life cycles.

\section{Conclusion}

A wide range of life cycles are found in nature and a considerable amount of theoretical work has gone into trying to explain why this should be so and into modelling the potential advantages of each type of life cycle. Advantages of both diploid and haploid life cycles have been proposed based on genetic factors, such as resistance to DNA damage or the advantages 
and disadvantages of masking deleterious or advantageous mutations in diploid individuals, and on indirect effects of ploidy such as cell size. Another set of models attempt to explain the evolutionary stability of haploid-diploid life cycles and invoke factors such a reduced cost of sex and the potential ability of organisms with such life cycles to exploit different ecological niches during each generation of the cycle. In contrast, only a limited number of experimental studies have been carried out to test these various hypotheses. In this review, we have underlined the potential of both established and emerging model organisms as tools to test theoretical hypotheses about the evolution and stability of different types of life cycle. By allowing genetic and genomic approaches, model organisms provide access to the molecular basis of life cycle events and the information generated by this sort of study can be used to address specific questions. For example, the identification of genes expressed specifically in either the sporophyte or the gametophyte provides vital information about the biology of each generation of the life cycle, permitting insights into potential differences between the ecological niches of the two generations. The availability of generation-specific genes also opens up the possibility of accessing the effects of selection pressure during the two generations of a life cycle. Moreover, genetic analysis of these model organisms aimed at identifying the regulatory cascades that control the progression of the life cycle are expected to provide insights into basic questions such as the relationship between ploidy and alternation of generations and how these two phenomena interact at the molecular level. Being able to answer such questions will represent an important step towards understanding the life cycles themselves. The remarkable advances in the development of technologies for the molecular analysis of model organisms in recent years has created a situation in which convergence between theoretical and experimental studies should be greatly facilitated and exciting progress can be expected in this domain in the coming years. 
Acknowledgements

We would like to thank Catherine Leblanc, Susan de Goer and Philippe Potin for their comments on the manuscript. This work was supported by the Centre National de Recherche Scientifique, the Région Bretagne, the European Union network of excellence Marine Genomics Europe, the Université Pierre and Marie Curie and by a long-term European Molecular Biology Organisation fellowship to SC.

Figures

Figure 1. Major types of sexual life cycle found in the eukaryotes. See text for details.

Figure 2. The complex life cycle of Ectocarpus siliculosus. Ectocarpus has a haploid-diploid cycle (grey boxes) involving an alternation between a diploid sporophyte and dioecious (male and female), haploid gametophytes. Several variations on this basic cycle have been observed in culture including the parthenogenetic development of haploid sporophytes from unfertilised gametes and the production of diploid gametophytes by tetraploid sporophytes (white boxes). Some of these variations, such as the production of tetraploid sporophytes for example, only occur rarely. Gametophytes produce gametes in plurilocular gametangia (P) whilst sporophtyes produce spores in either plurilocular (P) or unilocular (U) sporangia. Meiosis occurs in the unilocular sporangia. The presence of the male and female sex factors is indicated (in brackets for the sporophytes because the sex factor is only expressed phenotypically in the gametophyte). Adapted from Müller (1967). 
References

Adams, J. and Hansche, P.E., 1974. Population studies in microorganisms. I. Evolution of diploidy in Saccharomyces cerevisiae. Genetics 76, 327-338.

Albrecht, C., Russinova, E., Hecht, V., Baaijens, E., de Vries, S., 2005. The Arabidopsis thaliana SOMATIC EMBRYOGENESIS RECEPTOR-LIKE KINASES1 and 2 control male sporogenesis. Plant Cell 17, 3337-3349.

Acosta-Garcia, G., Vielle-Calzada, J.-P., 2004. A Classical Arabinogalactan Protein Is Essential for the Initiation of Female Gametogenesis in Arabidopsis. Plant Cell 16, $2614-2628$.

Agashe, B., Prasad, C.K., Siddiqi, I., 2002. Identification and analysis of DYAD: a gene required for meiotic chromosome organisation and female meiotic progression in Arabidopsis. Development 129, 3935-3943.

Ang, P.O. and De Wreede, R.E., 1990. Matrix models for algal life history stages. Marine Ecology Progress Series 59, 171-181.

Armstrong SJ, Caryl AP, Jones GH,Franklin FC. (2002) Asy1, a protein required for meiotic chromosome synapsis, localizes to axis-associated chromatin in Arabidopsis and Brassica. J Cell Sci. 115(Pt 18):3645-55.

Azumi Y, Liu D, Zhao D, Li W,Wang G, Hu Y, Ma H. (2002) Homolog interaction during meiotic prophase I in Arabidopsis requires the SOLO DANCERS gene encoding a novel cyclin-like protein. EMBO J. 21, 3081-95. 
Bai, X, Peirson, B.N., Dong, F., Xue, C., Makaroff, C.A., 1999. Isolation and characterization of SYN1, a RAD21-like gene essential for meiosis in Arabidopsis. Plant Cell 11, 417430.

Banks, J.A., 1999. Gametophyte development in ferns. Ann. Rev. Plant Physiol. Plant Mol. Biol., 50, 163-186.

Barrell, P.J., Grossniklaus, U., 2005. Confocal microscopy of whole ovules for analysis of reproductive development: the elongate1 mutant affects meiosis II. Plant J. 43, 309-320.

Baudino, S., Hansen, H., Brettschneider, R., Hecht, V.F.G., Dresselhaus, T., Lorz, H., Dumas, C., Rogowsky, P.M., 2001. Molecular characterisation of two novel maize LRR receptor-like kinases, which belong to the SERK gene family. Planta 213, 1-10.

Becker, J.D., Boavida, L.C., Carneiro, J., Haury, M., Feijo, J.A.., 2003. Transcriptional profiling of Arabidopsis tissues reveals the unique characteristics of the pollen transcriptome. Plant Physiol. 133, 713-725.

Bell, P.R., 1992. Apospory and apogamy: implications for understanding the plant life cycle. Int. J. Plant Sci. 153, S123-S136.

Bell, G., 1994. The comparative biology of the alternation of generations. In: Kirpatrick, M. (Ed.), Lectures on Mathematics in Life Sciences: The Evolution of Haplo-Diploid Life Cycles. American Mathematical Society, Providence, Rhode Island, pp. 1-26.

Bell, G., 1997. The evolution of the life cycle of brown seaweeds. Biol. J. Linnean Soc. 60, 21-38.

Bennici, A., 2005. A fundamental plant evolutionary problem: the origin of land-plant sporophyte; is a new hypothesis possible? Rivista di Biologia 98, 469-480.

Berleth, T., Chatfield, S., 2002. Embryogenesis: Pattern Formation from a Single Cell. In: Somerville, C.R., Meyerowitz, E.M. (Eds.), The Arabidopsis Book, American Society of Plant Biologists, Rockville, MD, pp. 1-22. 
Berthold, G., 1881. Die geschlechtliche Fortpflanzung der eigentlichen Phaeosporeen. Mitt. Zool. Stat. Neapel 2, 401-413.

Bhatt, A.M., Lister, C., Page, T., Fransz, P., Findlay, K., Jones, G.H., Dickinson, H.G., Dean, C., 1999.

Blackwell, W.H., 2003. Two Theories of Origin of the Land-Plant Sporophyte: Which Is Left Standing? Botanical Review 60, 125-148.

Boavida, L.C., Becker, J.D. and Feijo, J.A. 2005. The making of gametes in higher plants. Int. J. Dev. Biol. 49, 595-614.

Boutilier, K., Offringa, R., Sharma, V.K., Kieft, H., Ouellet, T., Zhang, L., Hattori, J., Liu, C.M., van Lammeren, A.A., Miki, B.L., Custers, J.B., van Lookeren Campagne, M.M., 2002. Ectopic expression of BABY BOOM triggers a conversion from vegetative to embryogenic growth. Plant Cell 14, 1737-1749.

Bower, F.O., 1908. The origin of a land Flora. Macmillan and Company, Limited, London.

Bräutigam, M., Klein, M., Knippers, R., Müller, D.G., 1995. Inheritance and meiotic elimination of a virus genome in the host Ectocarpus siliculosus (Phaeophyceae). Journal of Phycology 31, 823-827.

Byzova, M.V., Franken, J., Aarts, M.G., de Almeida-Engler, J., Engler, G., Mariani, C., Van Lookeren, Campagne, M.M., Angenent, G.C., 1999. Arabidopsis STERILE APETALA, a multifunctional gene regulating inflorescence, flower, and ovule development. Genes Dev. 13, 1002-1014.

Canales, C., Bhatt, A.M., Scott, R., Dickinson, H., 2002. EXS, a putative LRR receptor kinase, regulates male germline cell number and tapetal identity and promotes seed development in Arabidopsis. Curr Biol. 2, 1718-1727. 
Caryl, A.P., Armstrong, S.J., Jones, G.H., Franklin, F.C., 2000. A homologue of the yeast HOP1 gene is inactivated in the Arabidopsis meiotic mutant asyl. Chromosoma 109, $62-71$.

Caryl, A.P., Jones, G.H., Franklin, H.F., 2003. Dissecting plant meiosis using Arabidopsis thaliana mutants. J. Exp. Bot. 54, 25-38.

Carrington, E., Grace, S.P. and Chopin, T., 2001. Life history phases and the biomechanical properties of the red alga Chondrus crispus (Rhodophyta). J. Phycol. 37, 699-704.

Cavalier-Smith, T., 1978. Nuclear volume control by nucleoskeletal DNA, selection for cell volume and cell growth rate, and the solution of the DNA C-value paradox. J. Cell Sci 34, 247-278.

Chaudhury, A.M., Ming, L., Miller, C., Craig, S., Dennis, E.S., Peacock, W.J., 1997. Fertilization independent seed development in Arabidopsis thaliana. Proc. Natl. Acad. Sci. USA 94, 4223-4228.

Chen, Y.C., McCormick, S., 1996. Sidecar pollen, an Arabidopsis thaliana male gametophytic mutant with aberrant cell divisions during pollen development. Development 122, 3243-3253.

Cho, G. Y., Lee, S.H., Boo, S.M., 2004. A new brown algal order, Ishigeales (Phaeophyceae), established on the basis of plastid protein-coding $\mathrm{rbcL}$, psaA, and psbA region comparisons. J. Phycol. 40, 921-936.

Christensen, C.A., King, E.J., Jordan, J.R., Drews, G.N., 1997. Megagametogenesis in Arabidopsis wild type and the Gf mutant. Sex. Plant Reprod. 10, 49-64.

Christensen, C.A., Subramanian, S., Drews, G.N., 1998. Identification of gametophytic mutations affecting female gametophyte development in Arabidopsis. Dev. Biol. 202, $136-151$. 
Christensen, C.A., Gorsich, S.W., Brown, R.H., Jones, L.G., Brown, J., Shaw, J.M., Drews, G.N., 2002. Mitochondrial GFA2 is required for synergid cell death in Arabidopsis. Plant Cell 14, 2215-2232.

Clayton, M.N., 1988. Evolution and Life histories of Brown Algae. Botanica Marina 31, 379387.

Colcombet, J., Boisson-Dernier, A., Ros-Palau, R., Vera, C.E., Schroeder, J.I., 2005. Arabidopsis SOMATIC EMBRYOGENESIS RECEPTOR KINASES1 and 2 are essential for tapetum development and microspore maturation. Plant Cell 17, 33503361.

Couteau, F., Belzile, F., Horlow, C., Grandjean, O., Vezon, D., Doutriaux, M.P., 1999. Random chromosome segregation without meiotic arrest in both male and female meiocytes of a dmcl mutant of Arabidopsis. Plant Cell 11, 1623-1634.

Cronin, G. and Hay, M.E., 1996. Chemical defences, protein content, and susceptibility to herbivory of diploid vs. haploid stages of the isomorphic brown alga Dictyota ciliolata (Phaeophyta). Botanica Marina 39, 395-399.

Cunningham, E.M., Guiry, M.D. and Breeman, A.M., 1993. Environmental regulation of development, life history and biogeography of Helminthora stackhousei (Rhodophyta) by daylenght and temperature. J. Exp. Mar. Biol. Ecol. 171, 1-21.

Dai, S., Li, L., Chen, T., Chong, K., Xue, Y., Wang, T., 2006. Proteomic analyses of Oryza sativa mature pollen reveal novel proteins associated with pollen germination and tube growth. Proteomics 6, 2504-2529.

de Reviers, B., 2002. Biologie et phylogénie des algues, tome 1. Belin, Paris, pp. 352.

Destombe, C., Godin, J., Lefebvre, C., Dehorter, O. and Vernet, P., 1992. Differences in dispersal abilities of haploid and diploid spores of Gracilaria verrucosa (Gracilariales, Rhodophyta). Botanica Marina 35, 93-98. 
Destombe, C., Godin, J., Nocher, M., Richerd, S. and Valero, M., 1993. Differences in response between haploid and diploid isomorphic phases of Gracilaria verrucosa (Rhodophyta: Gigartinales) exposed to artificial environmental conditions. Hydrobiologia 260/261, 131-137.

Destombe, C., Valero, M., Vernet, P. and Couvet, D., 1989. What controls haploid-diploid ratio in the red alga, Gracilaria verrucosa? Journal of Evolutionary Biology 2, 317338.

DeYoung, B., Weber, T., Hass, B., Banks, J., 1997. Generating autotetraploid sporophytes and their use in analyzing mutations affecting gametophyte development in the fern Ceratopteris. Genetics 147, 809-814.

Delaroque, N., Müller, D.G., Bothe, G., Pohl, T., Knippers, R., Boland, W., 2001. The complete DNA sequence of the Ectocarpus siliculosus virus EsV-1 genome. Virology $287,112-132$.

Draisma, S.G.A., Peters A.F., Fletcher R.L., 2003. Evolution and taxonomy in the Phaeophyceae: effects of the molecular age on brown algal systematics. In: Norton, T. A. (Ed.), Out of the Past. Collected reviews to celebrate the jubilee of the British Phycological Society. The British Phycological Society, Belfast, pp. 87-102.

Dray, E., Siaud N., Dubois, E., Doutriaux, M.P., 2006. Interaction between Arabidopsis Brca2 and its partners Rad51, Dmc1, and Dss1. Plant Physiol. 140, 1059-1069.

Dresselhaus, T., Lorz, H., Kranz, E., 1994. Representative cDNA libraries from few plant cells. Plant J. 5, 605-610.

Drews, G.N., Yadegari, R., 2002. Development and function of the angiosperm female gametphyte. Ann. Rev. Genet. 36, 99-124.

Ebel, C., Mariconti, L., Gruissem, W., 2004. Plant retinoblastoma homologues control nuclear proliferation in the female gametophyte. Nature 429, 776-780. 
Elliott, R.C., Betzner, A.S., Huttner, E., Oakes, M.P., Tucker, W.Q., Gerentes, D., Perez, P., Smyth, D.R., 1996. AINTEGUMENTA, an APETALA2-like gene of Arabidopsis with pleiotropic roles in ovule development and floral organ growth. Plant Cell 8, 155-168.

Engel, C., Åberg, P., Gaggiotti, O., Destombe, C. and Valero, M., 2001. Population dynamics and stage structure in a haploid-diploid red seaweed, Gracilaria gracilis. J. Ecol. 89, 436-450.

Engel, C.R., Destombe, C. and Valero, M., 2004. Mating system and gene flow in the red seaweed Gracilaria gracilis: effect of haploid-diploid life history and intertidal rocky shore landscape on fine-scale genetic structure. Heredity 92, 289-298.

Engel, M., Chaboud, A., Dumas, C., McCormick, S., 2003. Sperm cells of Zea mays have a complex complement of mRNAs. Plant J. 34, 697-707.

Evans, M.M., 2007. The indeterminate gametophyte1 Gene of Maize Encodes a LOB Domain Protein Required for Embryo Sac and Leaf Development. Plant Cell, in press.

Fernando, D.D., 2005. Characterization of pollen tube development in Pinus strobus (Eastern white pine) through proteomic analysis of differentially expressed proteins. Proteomics $5,4917-4926$.

Fierst, J., terHorst, C., Kubler, J.E. and Dudgeon, S., 2005. Fertilization success can drive patterns of phase dominance in complex life histories. J. Phycol. 41, 238-249.

Floyd, S.K. and Bowman, J.L., 2007. The ancestral developmental tool kit of land plants. Int. J. Plant Sci. 168, 1-35.

Gallego, M.E., Jeanneau, M., Granier, F., Bouchez, D., Bechtold, N., White, C.I., 2001. Disruption of the Arabidopsis RAD50 gene leads to plant sterility and MMS sensitivity. Plant J. 25, 31-41.

Gallego, M.E., White, C.I., 2001. RAD50 function is essential for telomere maintenance in Arabidopsis. Proc. Natl. Acad. Sci. USA 98, 1711-1716. 
Gallois, P., 2001. Future of early embryogenesis studies in Arabidopsis thaliana. C.R. Acad. Sci. Life Sciences 324, 569-573.

Gerstein, A.C., Chun, H.-J.E., Grant, A. and Otto, S.P., 2006. Genomic convergence toward diploidy in Saccharomyces cerevisiae. PLoS Genetics 2, 1393-1401.

Glover, J., Grelon, M., Craig, S., Chaudhury, A., Dennis, E., 1998. Cloning and characterization of MS5 from Arabidopsis: a gene critical in male meiosis. Plant J. 15, 345-356.

Grelon, M., Vezon, D., Gendrot, G., Pelletier, G., 2001. AtSPO11-1 is necessary for efficient meiotic recombination in plants. EMBO J. 20, 589-600.

Gross-Hardt, R., Kagi, C., Baumann, N., Moore, J.M., Baskar, R., Gagliano, W.B., Jurgens, G., Grossniklaus, U., 2007. LACHESIS Restricts Gametic Cell Fate in the Female Gametophyte of Arabidopsis. PLoS Biol. in press.

Grossniklaus, U., Vielle-Calzada, J.P., Hoeppner, M.A, Gagliano, W.B., 1998. Maternal control of embryogenesis by MEDEA, a polycomb group gene in Arabidopsis. Science $280,446-450$.

Guiry, M. D., 1987. The evolution of life history types in the Rhodophyta: an appraisal. Cryptogamie, Algologie 8, 1-12.

Guitton, A.E., Berger, F., 2005a. Control of reproduction by Polycomb group complexes in animals and plants. Int. J. Dev. Biol. 49, 707-716.

Guitton, A.E., Berger, F., 2005b. Loss of function of MULTICOPY SUPPRESSOR OF IRA 1 produces nonviable parthenogenetic embryos in Arabidopsis. Curr. Biol. 15, 750-754.

Hall, D.W., 2000. The evolution of haploid, diploid and polymorphic haploid-diploid life cycles: the role of meiotic mutation. Genetics 156, 893-898.

Hansche, P.E., 1974. Gene duplication as a mechanism of genetic adaptation in Saccharomyces cerevisiae. Genetics 79, 661-674. 
Hawkes, M.W., 1978. Sexual reproduction in Porphyra gardneri (Smith et Hollenberg) Hawkes (Bangiales, Rhodophyta). Phycologia 16, 329-353.

Hawkes, M.W., 1990. Reproductive strategies. In: Cole, K.M., Sheath, R.G. (Eds.), Biology of the red algae. Cambridge University Press, Cambridge, pp. 455-476.

He, C., Mascarenhas, J.P., 1998. MEI1, an Arabidopsis gene required for male meiosis: isolation and characterization. Sex. Plant Reprod. 11, 199-207.

Hejatko, J., Pernisova, M., Eneva, T., Palme, K., Brzobohaty, B., 2003. The putative sensor histidine kinase CKII is involved in female gametophyte development in Arabidopsis. Mol. Genet. Genom. 269, 443-453.

Hofmeister, W., 1851. Vergleichende Untersuchungen der Keimung, Entfaltung und Fruchtbildildiung höherer Kryptogamen (Moose, Farne, Equisetaceen, Rhizocarpeen und Lycopodiaceen) und der Samenbildung der Coniferen. F. Hofmeister, Leipzig.

Holmes-Davis, R., Tanaka, C.K., Vensel, W.H., Hurkman, W.J., McCormick, S., 2005. Proteome mapping of mature pollen of Arabidopsis thaliana. Proteomics 5, 4864-4884.

Honys, D., Twell, D., 2003. Comparative analysis of the Arabidopsis pollen transcriptome. Plant Physiol. 132, 640-52.

Honys, D., Twell D.,2004. Transcriptome analysis of haploid male gametophyte development in Arabidopsis. Genome Biol. 5, R85.1-R85.13.

Howden, R., Park, S.K., Moore, J.M., Orme, J., Grossniklaus, U., Twell, D., 1998. Selection of T-DNA-tagged male and female gametophytic mutants by segregation distortion in Arabidopsis. Genetics 149, 621-631.

Huanca-Mamani, W., Garcia-Aguilar, M., Leon-Martinez, G., Grossniklaus, U., VielleCalzada, J.P., 2005. CHR11, a chromatin-remodeling factor essential for nuclear proliferation during female gametogenesis in Arabidopsis thaliana. Proc. Natl. Acad. Sci. USA 102, 17231-17236. 
Huang, B.Q., Sheridan, W.F., 1996. Embryo Sac Development in the Maize indeterminate gametophyte1 Mutant: Abnormal Nuclear Behavior and Defective Microtubule Organization. Plant Cell 8, 1391-1407.

Hughes, J.S., Otto, S.P., 1999. Ecology and the evolution of biphasic life cycles. Am. Nat. $154,306-320$.

Hulskamp, M., Parekh, N.S., Grini, P., Schneitz, K., Zimmermann, I., Lolle, S.J., Pruitt, R.E., 1997. The STUD gene is required for male-specific cytokinesis after telophase II of meiosis in Arabidopsis thaliana. Dev Biol. 187, 114-124.

Iwakawa, H., Shinmyo, A., Sekine, M.,. 2006. Arabidopsis CDKA;1, a cdc2 homologue, controls proliferation of generative cells in male gametogenesis. Plant J. 45, 819-831.

Jenkins, C.D., Kirkpatrick, M., 1995. Deleterious mutations and the evolution of genetic life cycles. Evolution 49, 512-520.

Johnson, S.A., McCormick, S., 2001 Pollen germinates precociously in the anthers of raringto-go, an Arabidopsis gametophytic mutant. Plant Physiol. 126, 685-695.

Jung, K.H., Han, M.J., Lee, Y.S., Kim, Y.W., Hwang, I., Kim, M.J., Kim, Y.K., Nahm, B.H., An, G., 2005. Rice Undeveloped Tapetuml is a major regulator of early tapetum development. Plant Cell 17, 2705-2722.

Kasahara, R.D., Portereiko, M.F., Sandaklie-Nikolova, L., Rabiger, D.S., Drews, G.N., 2005. MYB98 is required for pollen tube guidance and synergid cell differentiation in Arabidopsis. Plant Cell 17, 2981-2992.

Kawai, H., Hanyuda, T., Draisma, S.G.A., Müller, D.G., 2007. Molecular phylogeny of Discosporangium mesarthrocarpum (Phaeophyceae) with a reassessment of the order Discosporangiales. J. Phycol. in press.

Keddy, P.A., 1981. Why gametophytes and sporophytes are different: form and function in a terrestrial environment. Am. Nat. 118, 452-454. 
Kenrick, P., Crane, P.R., 1997. The origin and early diversification of land plants; a cladistic study. Smithsonian Institution Press, Washington, pp. 29-30.

Kerim, T., Imin, N., Weinman, J.J., Rolfe, B.G., 2003. Proteome analysis of male gametophyte development in rice anthers. Proteomics 3, 738-51.

Kerzendorfer, C., Vignard, J., Pedrosa-Harand, A., Siwiec, T., Akimcheva, S., Jolivet, S., Sablowski, R., Armstrong, S., Schweizer, D., Mercier, R., Schlogelhofer, P., 2006. The Arabidopsis thaliana MND1 homologue plays a key role in meiotic homologous pairing, synapsis and recombination. J. Cell Sci.19, 2486-2496.

Kieber, J.J., Rothenberg, M., Roman, G., Feldmann, K.A., Ecker, J.R. 1993. CTR1, a negative regulator of the ethylene response pathway in Arabidopsis, encodes a member of the raf family of protein kinases. Cell 72, 427-441.

Kim, H.U., Li, Y., Huang, A.H., 2005. Ubiquitous and endoplasmic reticulum-located lysophosphatidyl acyltransferase, LPAT2, is essential for female but not male gametophyte development in Arabidopsis. Plant Cell 17, 1073-1089.

Kitade, Y., Iitsuka, O., Fukuda, S., Saga, N., 2004. Porphyra yezoensis as a model plant for genome sciences. Jpn. J. Phycol. 52(suppl), 129-31.

Klinger, T., 1993. The persistence of haplodiploidy in algae. Trends in Ecology and Evolution $8,256-258$.

Klimyuk, V.I., Jones, J.D., 1997. AtDMC1, the Arabidopsis homologue of the yeast DMC1 gene: characterization, transposon-induced allelic variation and meiosis-associated expression. Plant J. 11, 1-14.

Klucher, K.M., Chow, H., Reiser, L., Fischer, R.L., 1996. The AINTEGUMENTA gene of Arabidopsis required for ovule and female gametophyte development is related to the floral homeotic gene APETALA2. Plant Cell 8, 137-153.

Kondrashov, A.S., 1997. Evolutionary genetics of life cycles. Annual Rev. Ecol. Systematics 
28, 391-435.

Kornmann, P., 1956. Über die Entwicklung einer Ectocarpus confervoides-Form. Pubblicazioni della stazione zoologica di Napoli 28, 32-43.

Krumbiegel, G., 1979. Reponse of haploid and diploid protoplansts from Datura innoxia Mill. and Petunia hybrida L. to treatment with x-rays and a chemical mutagen. Environ. Exp. Bot. 19, 99-103.

Kwee, H.S., Sundaresan, V. 2003. The NOMEGA gene required for female gametophyte development encodes the putative APC6/CDC16 component of the Anaphase Promoting Complex in Arabidopsis. Plant J. 36, 853-866.

Lalanne, E., Twell, D., 2002. Genetic control of male germ unit organization in Arabidopsis. Plant Physiol. 129, 865-875.

Lalanne, E., Michaelidis, C., Moore, J.M., Gagliano, W., Johnson, A., Patel, R., Howden, R., Vielle-Calzada, J.P., Grossniklaus, U., Twell, D., 2004. Analysis of transposon insertion mutants highlights the diversity of mechanisms underlying male progamic development in Arabidopsis. Genetics 167, 1975-1986.

Lang, W.H., 1909. A Theory of Alternation of Generations in Archegoniate Plants Based Upon the Ontogeny. New Phytologist 8, 1-12.

Le, Q., Gutierrez-Marcos, J.F., Costa, L.M., Meyer, S., Dickinson, H.G., Lorz, H., Kranz, E., Scholten, S., 2005 Construction and screening of subtracted cDNA libraries from limited populations of plant cells: a comparative analysis of gene expression between maize egg cells and central cells. Plant J. 44, 167-178.

Lee, Y.K., Choi, H.G., Hong C.B., Lee. I.K., 1995. Sexual differentiation of Griffithsia (Ceramiales, Rhodophyta): nuclear ploidy level of mixed-phase plants in G. japonica. Journal of Phycology 31, 668-673. 
Lee, J.Y., Lee, D.H., 2003. Use of serial analysis of gene expression technology to reveal changes in gene expression in Arabidopsis pollen undergoing cold stress. Plant Physiol. $132,517-29$.

Leitch, I.J., Bennett, M.D., 1997. Polyploidy in angiosperms. Trends Pl. Sci. 2, 470-476.

Lewis Jr, W.M., 1984. Nutrient scarcity as an evolutionary cause of haploidy. Am.Nat. 125, 692-701.

Lewis, L.A. and McCourt, R.M., 2004. Green algae and the origin of land plants. Amer. J. Botany 91, 1535-1556.

Lotan, T., Ohto, M., Yee, K.M., West, M.A.L., Lo, R., Kwong, R.W., Yamagishi, K., Fischer, R.L., Goldberg, R.B., Harada, J.J., 1998. Arabidopsis LEAFY COTYLEDON1 is sufficient to induce embryo development in vegetative cells. Cell 93, 1195-1205.

Lubchenco, J. and Cubit, J., 1980. Heteromorphic life histories of certain marine algae as adaptations to variations in herbivory. Ecology 61, 676-687.

Lynch M., Blanchard J., Houle D., Kibota T., Schultz S., Vassilieva L. and Willis G., 1999. Perspective: spontaneous deleterious mutation. Evolution 53, 645-663.

Mable, B., Otto, S., 1998. The evolution of life cycles with haploid and diploid phases. BioEssays 20, 453-462.

Magnard, J.L., Yang, M., Chen, Y.C., Leary, M., McCormick, S., 2001. The Arabidopsis gene tardy asynchronous meiosis is required for the normal pace and synchrony of cell division during male meiosis. Plant Physiol. 127, 1157-1166.

Maraschin, S.F., de Priester, W., Spaink, H. P., Wang M., 2005. Androgenic switch: an example of plant embryogenesis from the male gametophyte perspective. J. Exp. Bot. $56,1711-1726$.

Mascarenhas, J.P., 1990. Gene activity during pollen development. Ann. Rev. Plant Physiol. 41, 317-388. 
Mayfield, J.A., Fiebig, A., Johnstone, S.E., Preuss, D., 2001. Gene families from the Arabidopsis thaliana pollen coat proteome. Science 292, 2482-2485.

McCormick, S., 1993. Male Gametophyte Development. Plant Cell 5, 1265-1275.

McCormick, S., 2004. Control of male gametophyte development. Plant Cell 16, S142-S153.

Mezger-Freed, L., 1974. An Analysis of Survival in haploid cell cultures after exposure to ICR acridine half- mustard compounds mutagenic for bacteria. Proc. Natl. Acad. Sci. USA 71, 4416-4420.

Michod, R.E., Gayley, T., 1994. Genetic error, heterozygosity and the evolution of the sexual life cycle. Lectures on Mathematics in Life Sciences: The Evolution of Haplo-Diploid Life Cycles 25, 97-119.

Mercier, R., Armstrong, S.J., Horlow, C., Jackson, N.P., Makaroff, C.A., Vezon, D., Pelletier, G., Jones, G.H., Franklin, C.H., 2003. The meiotic protein SWI1 is required for axial element formation and recombination initiation in Arabidopsis. Development 130, 33093318.

Mitman, G.G., van der Meer, J. P., 1994. Meiosis, blade development, and sex determination in Porphyra purpurea (Rhodophyta). J. Phycol. 30, 147-159.

Moore, J.M., Calzada, J.P., Gagliano, W., Grossniklaus, U., 1997. Genetic characterization of hadad, a mutant disrupting female gametogenesis in Arabidopsis thaliana. Cold Spring Harb. Symp. Quant. Biol. 62, 35-47.

Mori, T., Kuroiwa, H., Higashiyama, T., Kuroiwa, T., 2006. GENERATIVE CELL SPECIFIC 1 is essential for angiosperm fertilization. Nat. Cell Biol. 8, 64-71.

Mulcahy, D.L., 1979. The rise of the angiosperms: a genecological factor. Science 206, 2023.

Mulcahy, D.L., Mulcahy, G.B., 1975. The influence of gametophytic competition on sporophytic quality in Dianthus chinensis. Theor. Appl. Genet. 46, 277-280. 
Müller, D.G., 1967. Generationswechsel, Kernphasenwechsel und Sexualität der Braunalge Ectocarpus siliculosus im Kulturversuch. Planta 75, 39-54.

Müller, D.G., 1976. Relative sexuality in Ectocarpus siliculosus. A scientific error. Arch. Microbiol. 109, 89-94.

Müller, D.G., Jaenicke, L., Donike, M., Akintobi, T., 1971. Sex attractant in a brown alga: chemical structure. Science 171, 815-817.

Müller, D.G., Kawai, H., Stache, B., Lanka, S., 1990. A virus infection in the marine brown alga Ectocarpus siliculosus (Phaeophyceae). Botanica Acta 103, 72-82.

Müller, D.G., Kapp, M., Knippers, R., 1998. Viruses in marine brown algae. Adv. Virus Res. $50,49-67$.

Niewiadomski, P., Knappe, S., Geimer, S., Fischer, K., Schulz, B., Unte, U.S., Rosso, M.G., Ache, P., Flugge, U.I., Schneider, A., 2005. The Arabidopsis plastidic glucose 6phosphate/phosphate translocator GPT1 is essential for pollen maturation and embryo sac development. Plant Cell 17, 760-775.

Nishiyama, T., Fujita, T., Shin-I, T., Seki, M., Nishide, H., Uchiyama, I., Kamiya, A., Carninci, P., Hayashizaki, Y., Shinozaki, K., Kohara, Y., Hasebe, M., 2003. Comparative genomics of Physcomitrella patens gametophytic transcriptome and Arabidopsis thaliana: implication for land plant evolution. Proc. Natl. Acad. Sci. USA. $100,8007-8012$.

Nogler, G.A., 1984. Gametophytic apomixis. In: Johri, B.M. (Ed.), Embryology of angiosperms, Springer, Berlin, pp. 475-518.

Noir, S., Brautigam, A., Colby, T., Schmidt, J., Panstruga, R., 2005. A reference map of the Arabidopsis thaliana mature pollen proteome. Biochem. Biophys. Res. Comm. 337, $1257-1266$.

Nonomura K., Miyoshi, K., Eiguchi, M., Suzuki, T., Miyao, A., Hirochika, H., Kurata, N., 
2003. The MSP1 gene is necessary to restrict the number of cells entering into male and female sporogenesis and to initiate anther wall formation in rice. Plant Cell 15, 17281739.

Nuismer, S.L., Otto, S.P., 2004. Host-parasite interactions and the evolution of ploidy. Proc. Natl. Acad. Sci. USA 101, 11036-11039.

Oh, S.-A., Park, S.K., Jang, I., Howden, R., Moore, J.M., Grossniklaus, U., Twell, D., 2003. halfman, an Arabidopsis male gametophytic mutant associated with a $150 \mathrm{~kb}$ chromosomal deletion adjacent to an introduced Ds transposable element. Sex. Plant Reprod. 16, 99-102.

Ohme, M., Miura, A., 1988. Tetrad analysis in conchospore germlings of Porphyra yezoensis (Rhodophyta, Bangiales). Plant Science 57, 135-140.

Orr, H.A., Otto, S.P., 1994. Does diploidy increase the rate of adaptation? Genetics 136, $1475-1480$.

Otto, S.P., Goldstein, D.B., 1992. Recombination and the evolution of diploidy. Genetics 131, $745-751$.

Otto, S.P., Marks, J.C., 1996. Mating systems and the evolutionary transition between haploidy and diploidy. Biol. J. Linnean Soc. 57, 197-218.

Pagnussat, G.C., Yu, H.-J., Ngo, Q.A., Rajani1, S., Mayalagu, S., Johnson, C., Capron, A., Xie, L.-F., Ye, D., Sundaresan, V., 2005. Genetic and molecular identification of genes required for female gametophyte development and function in Arabidopsis. Development 132, 603-614.

Paquin, C., Adams, J., 1983. Frequency of fixation of adaptive mutations is higher in evolving diploid than haploid yeast populations. Nature 302, 495-500. 
Park, S.K., Howden, R., Twell, D., 1998. The Arabidopsis thaliana gametophytic mutation gemini pollen1 disrupts microspore polarity, division asymmetry and pollen cell fate. Development 125, 3789-3799.

Perrot, V., 1994. Experimental approaches to the evolution of life cycles. In: Kirpatrick, M. (Ed.), Proceedings of the 1993 symposium on some mathematical questions in biology. American Mathematical Society, Providence, pp. 121-134.

Perrot, V., Richerd, S., Valero, M., 1991. Transition from haploidy to diploidy. Nature 351, $315-317$.

Peters, A.F., Ramírez M.E., 2001. Molecular phylogeny of small brown algae, with special reference to the systematic position of Caepidium antarcticum (Adenocystaceae, Ectocarpales). Cryptogamie, Algologie 22, 187-200.

Peters, A.F., Marie, D., Scornet, D., Kloareg, B., Cock J.M., 2004. Proposal of Ectocarpus siliculosus as a model organism for brown algal genetics and genomics. J. Phycol. 40, 1079-1088.

Pina, C., Pinto, F., Feijo, J.A., Becker, J.D., 2005. Gene family analysis of the Arabidopsis pollen transcriptome reveals biological implications for cell growth, division control, and gene expression regulation. Plant Physiol. 138, 744-56.

Pischke, M.S., Jones, L.G., Otsuga, D., Fernandez, D.E., Drews, G.N., Sussman, M.R., 2002. An Arabidopsis histidine kinase is essential for megagametogenesis. Proc. Natl. Acad. Sci. USA 99, 15800-15805.

Portereiko, M.F., Sandaklie-Nikolova, L., Lloyd, A., Dever, C.A., Otsuga, D., Drews G.N., 2006. NUCLEAR FUSION DEFECTIVE1 encodes the Arabidopsis RPL21M protein and is required for karyogamy during female gametophyte development and fertilization. Plant Physiol. 141, 957-965.

Potin, P., Bouarab, K., Kuepper, F.C. and Kloareg, B., 1999. Oligosaccharide recognition 
signals and defence reactions in marine plant-microbe interactions. Curr. Opin. Microbiol. 2, 276-283.

Puizina, J., Siroky, J., Mokros, P., Schweizer, D., Riha, K., 2004. Mre11 deficiency in Arabidopsis is associated with chromosomal instability in somatic cells and Spo11dependent genome fragmentation during meiosis. Plant Cell 16, 1968-1978.

Qiu, Y.L., Li, L., Wang, B., Chen, Z., Knoop, V., Groth-Malonek, M., Dombrovska, O., Lee, J., Kent, L,. Rest, J., Estabrook, G.F., Hendry, T.A., Taylor, D.W., Testa, C.M., Ambros, M., Crandall-Stotler, B., Duff, R.J., Stech, M,. Frey, W., Quandt, D., 2006. The deepest divergences in land plants inferred from phylogenomic evidence. Proc. Natl. Acad. Sci. USA, 103, 15511-15516.

Quatrano, R.S., McDaniel, S.F., Khandelwal, A., Perroud, P.F., Cove, D.J., 2007. Physcomitrella patens: mosses enter the genomic age. Curr. Opin. Plant Biol. 10, 182189.

Raper, J.R., Flexer, A.S., 1970. The road to diploidy with emphasis on a detour. Symp. Soc. Gen. Microbiol 20, 401-432.

Reddy, T.V., Kaur, J., Agashe, B., Sundaresan, V., Siddiqi, I., 2003. The DUET gene is necessary for chromosome organization and progression during male meiosis in Arabidopsis and encodes a PHD finger protein. Development 130, 5975-5987.

Redei, G.P., 1965. Non mandelian megagametogenesis in Arabidopsis. Genetics 51, 857-872

Reiser, L., Modrusan, Z., Margossian, L., Samach, A., Ohad, N., Haughn, G.W., Fischer, R.L., 1995. The BELL1 gene encodes a homeodomain protein involved in pattern formation in the Arabidopsis ovule primordium. Cell 83, 735-742.

Rhee, S.Y., Osborne, E., Poindexter, P.D., Somerville, C.R., 2003. Microspore separation in the quartet 3 mutants of Arabidopsis is impaired by a defect in a developmentally 
regulated polygalacturonase required for pollen mother cell wall degradation. Plant Physiol. 133, 1170-1180.

Rhee, S.Y., Somerville, C.R., 1998. Tetrad pollen formation in quartet mutants of Arabidopsis thaliana is associated with persistence of pectic polysaccharides of the pollen mother cell wall. Plant J. 15, 79-88.

Richerd, S., Couvet, D. and Valero, M., 1993. Evolution of haploid and diploid phases in life cycles. II. Maintenance of the haplo-diplontic cycle. J. Evol. Biol. 6, 263-280.

Richerd, S., Perrot, V., Couvet, D., Valero, M. and Kondrashov, A.S., 1994. Deleterious mutations can account for the maintenance of the haplo-diploid cycle. In: Beaumont, A.R. (Ed.), Genetics and Evolution of Aquatic Organisms. Chapman \& Hall, London, Glasgow, New York, Tokyo, Melbourne, Madras, pp. 359-367.

Ross, K.J., Fransz, P., Armstrong, S.J., Vizir, I., Mulligan, B., Franklin, F.C., Jones, G.H., 1997. Cytological characterization of four meiotic mutants of Arabidopsis isolated from T-DNA-transformed lines. Chromosome Res. 5, 551-559.

Sanders, P.M., Bui, A.Q., Weterings, K., McIntire, K.N., Hsu, Y.-C., Lee, P.Y., Truong, M.T., Beals, T.P., Goldberg, R.B., 1999. Anther developmental defects in Arabidopsis thaliana male-sterile mutants. Sex Plant Reprod 11, 297-322.

Schiefthaler, U., Balasubramanian, S., Sieber, P.,Chevalier, D.,Wisman, E., Schneitz, K.,1999. Molecular analysis of NOZZLE, a gene involved in pattern formation and early sporogenesis during sex organ development in Arabidopsis thaliana. Proc Natl Acad Sci U S A 96, 11664-11669.

Schmidt, E.D.L., Guzzo, F., Toonen, M.A.J., de Vries, S.C., 1997. A leucine-rich repeat containing receptor-like kinase marks somatic plant cells competent to form embryos. Development 124, 2049-2062.

Schoustra, S.E., Slakhorst, M., Debets, A.J.M. and Hoekstra, R.F., 2005. Comparing artificial 
and natural selection in rate of adaptation to genetic stress in Aspergillus nidulans. J. Evol. Biol. 18, 771-778.

Searles, R.B., 1978. The strategy of red algal life history. American Naturalist 115, 113-120.

Seoighe, C., Gehring, C., Hurst, L.D., 2005. Gametophytic Selection in Arabidopsis thaliana Supports the Selective Model of Intron Length Reduction. PLoS Genetics 1, 144-158.

Sheridan, W.F., Avalkina, N.A., Shamrov, I.I., Batygina, T.B., Golubovskaya, I.N., 1996. The mac1 gene: controlling the commitment to the meiotic pathway in maize. Genetics 142 , 1009-1020.

Shi, D.Q., Liu, J., Xiang, Y.H., Ye, D., Sundaresan, V., Yang, W.C., 2005. SLOW WALKER1, essential for gametogenesis in Arabidopsis, encodes a WD40 protein involved in 18S ribosomal RNA biogenesis. Plant Cell 17, 2340-2354.

Siaud, N., Dray, E., Gy, I., Gerard, E., Takvorian, N., Doutriaux, M.P. 2004. Brca2 is involved in meiosis in Arabidopsis thaliana as suggested by its interaction with Dmcl. EMBO J. 24, 1392-1401.

Siddiqi, I., Ganesh, G., Grossniklaus, U., Subbiah, V., 2000. The dyad gene is required for progression through female meiosis in Arabidopsis. Development 127, 197-207.

Sliva, P., Kluz, J. and Korona, R., 2004. Mutational load and the transition between diploidy and haploidy in experimental populations of the yeast Saccharomyces cerevisiae. Genetica 121, 285-293.

Sorensen, A., Guerineau, F., Canales-Holzeis, C., Dickinson, H.G., Scott, R.J., 2002. A novel extinction screen in Arabidopsis thaliana identifies mutant plants defective in early microsporangial development. Plant J. 20, 581-594.

Sorensen, A.M., Krober, S., Unte, U.S., Huijser, P., Dekker, K., Saedler, H., 2003. The Arabidopsis ABORTED MICROSPORES (AMS) gene encodes a MYC class transcription factor. Plant J. 33, 413-23. 
Spielman, M., Preuss, D., Li, F.L., Browne, W.E., Scott, R.J., Dickinson, H.G., 1997. TETRASPORE is required for male meiotic cytokinesis in Arabidopsis thaliana. Development 124, 2645-2657.

Springer, P.S., McCombie, W.R., Sundaresan, V., Martienssen, R.A., 1995. Gene trap tagging of PROLIFERA, an essential MCM2-3-5-like gene in Arabidopsis. Science 268, 877880.

Sprunck, S.,Baumann, U., Edwards, K., Langridge, P. „Dresselhaus, T., 2005. The transcript composition of egg cells changes significantly following fertilization in wheat (Triticum aestivum L.). Plant J. 41, 660-672.

Stebbins, G.L., Hill, G.J., 1978. Did multicellular plants invade the land? Am. Nat. 115, 342353.

Steenstrup, J.J., 1845. On the alternation of generations or, the propagation and development of animals through alternate generations. English translation by Busk G. London, The Royal Society.

Stone, S.L., Kwong, L.W., Yee, K.M., Pelletier, J., Lepiniec, L., Fischer, R.L., Goldberg, R.B., and Harada, J.J., 2001. LEAFY COTYLEDON2 encodes a B3 domain transcription factor that induces embryo development. Proc. Natl. Acad. Sci. USA 98, 11806-11811.

Strasburger, E., 1894. The periodic reduction of the number of the chromosomes in the lifehistory of living organisms. Annals of Botany 8, 281-316.

Taylor, L.P., Hepler, P.K., 1997. Pollen germination and tube growth. Annu. Rev. Plant Physiol. Plant Mol. Biol. 48, 461-491.

Taylor, T.N., Kerp, H. and Hass, H., 2005. Life history biology of early land plants: Deciphering the gametophyte phase. Proc. Nat. Acad. Sci. USA 102, 5892-5897.

Thornber, C.S., 2006. Functional properties of the isomorphic biphasic algal life cycle. Integrative and Comparative Biology 46, 605-614. 
Thornber, C.S. and Gaines, S.D., 2004. Population demographics in species with biphasic life cycles. Ecology 85, 1661-1674.

Twell, D., Park, S.K., Lalanne, E., 1998. Asymmetric division and cell fate determination in developing pollen. Trends in Plant Sciences 3, 305-310.

Twell, D., Park, S.K., Hawkins, T.J., Schubert, D., Schmidt, R., Smertenko, A., Hussey, P.J., 2002. MOR1/GEM1 has an essential role in the plant-specific cytokinetic phragmoplast. Nat. Cell. Biol. 4, 711-714.

Uwai, S., Masuda, M., 1999. Pterosiphonia tanakae (Rhodomelaceae, Ceramiales), a new red algal species from Japan. Phycological Research 47, 421-250.

Valero, M., Richerd, S., Perrot, V., Destombe, C., 1992. Evolution of alternation of haploid and diploid phases in life cycles. Trends Ecol. Evol. 7, 25-29.

van den Hoek, C., Mann, D. G. and Jahns, H. M. 1995. Algae. An Introduction to Phycology. Cambridge University Press, Cambridge, pp. 623.

van der Meer, J.P., Todd, E.R., 1977. Genetics of Gracilaria sp (Rhodomelaceae, Gigartinales). IV. Mitotic recombination and its relationship to mixed phases in the life history. Can. J. Bot. 55, 2810-2817.

Vizcay-Barrena, G., Wilson, Z.A., 2006. Altered tapetal PCD and pollen wall development in the Arabidopsis ms1 mutant. J. Exp. Bot. 57, 2709-2717.

Waaland, J.R., Stiller, J.W., Cheney, D.P., 2004. Macroalgal candidates for genomics. J. Phycol. 40, 26-33.

Waters, R., Moustacchi, E., 1975. Dose Dependence of the Excision of Ultraviolet-Induced Pyrimidine Dimers from Nuclear Deoxyribonucleic Acids of Haploid and Diploid Saccharomyces cerevisiae. J. Bact. 121, 901-906.

Watkins, J.E., Farrar, D.R., 2005. Origin and taxonomic affinities of Thelypteris (subgen. Stegnogramma) burksiorum (Thelypteridaceae). Brittonia 57, 183-201. 
Weterings, K., Russell, S.D., 2004. Experimental analysis of the fertilization process. Plant Cell 16, S107-S118.

Wijeratne, A.J., Chen, C., Zhang, W., Timofejeva, L., Ma, H. 2006. The Arabidopsis thaliana PARTING DANCERS gene encoding a novel protein is required for normal meiotic homologous recombination. Mol. Biol. Cell. 17, 1331-1343.

Willson, M.F. 1981. On the evolution of complex life cycles in plants: a review and an ecological perspective. Ann. Missouri. Bot. Gard. 68, 275-300.

Wilson, Z.A., Morroll, S.M., Dawson, J., Swarup, R., Tighe, P.J., 2001. The Arabidopsis MALE STERILITY1 (MS1) gene is a transcriptional regulator of male gametogenesis, with homology to the PHD-finger family of transcription factors. Plant J. 28, 27-39.

Wilson, Z.A., Yang ,C. 2004. Plant gametogenesis: conservation and contrasts in development. Reproduction 128, 483-492.

Yadegaria, R. and Drews, G.N., 2004. Female Gametophyte Development. Plant Cell 16, S133-S141.

Yang, S.L., Xie, L.F., Mao, H.Z., Puah, C.S., Yang, W.C., Jiang, L., Sundaresan, V., Ye, D., 2003. Tapetum determinant 1 is required for cell specialization in the Arabidopsis anther. Plant Cell 15, 2792-2804.

Yang, W.C., Ye, D., Xu, J., Sundaresan, V., 1999. The SPOROCYTELESS gene of Arabidopsis is required for initiation of sporogenesis and encodes a novel nuclear protein. Genes Dev. 13, 2108 - 2117.

Yang, W.C., Sundaresan, V., 2000. Genetics of gametophyte biogenesis in Arabidopsis. Curr Opin Plant Biol. 3, 53-57.

Yang, X., Makaroff, C.A., Ma, H., 2003. The Arabidopsis MALE MEIOCYTE DEATH1 gene encodes a PHD-finger protein that is required for male meiosis. Plant Cell 15, 1281-1295. 
Yang, X., Timofejeva, L., Ma, H., Makaroff, C.A., 2006. The Arabidopsis SKP1 homolog ASK1 controls meiotic chromosome remodeling and release of chromatin from the nuclear membrane and nucleolus. J. Cell Sci. 119, 3754-3763.

Yoon, H. S., Ciniglia, C., Wu, M., Comeron, J. M., Pinto, G., Pollio, A., Bhattacharya, D., 2006. Establishment of endolithic populations of extremophilic Cyanidiales (Rhodophyta). BMC Evolutionary Biol 6, 78-89.

Yu, H.J., Hogan, P., Sundaresan, V., 2005. Analysis of the female gametophyte transcriptome of Arabidopsis by comparative expression profiling. Plant Physiol. 139, 1853-1869.

Zeyl, C., 2004. Experimental studies of ploidy evolution in yeast. Fems Microbiology Letters 233, $187-192$.

Zeyl, C., Vanderford, T. and Carter, M., 2003. An evolutionary advantage of haploidy in large yeast populations. Science 299, 555-558.

Zhang, W., Sun, Y., Timofejeva, L., Chen, C., Grossniklaus, U., Ma H., 2006. Regulation of Arabidopsis tapetum development and function by DYSFUNCTIONAL TAPETUM1 (DYT1) encoding a putative bHLH transcription factor. Development 133, 3085-3095.

Zhao, D.Z., Wang, G.F., Speal, B., Ma, H., 2002. The excess microsporocytes1 gene encodes a putative leucine-rich repeat receptor protein kinase that controls somatic and reproductive cell fates in the Arabidopsis anther. Genes Dev. 16, 2021-2031.

Zhao, D., Yang, X., Quan, L., Timofejeva, L., Rigel, N.W., Ma, H., Makaroff, C.A., 2006. $A S K 1$, a SKP1 homolog, is required for nuclear reorganization, presynaptic homolog juxtaposition and the proper distribution of cohesin during meiosis in Arabidopsis. Plant Mol Biol. 62, 99-110. 
Table 1. Definitions of some of the terms used in the text.

\begin{tabular}{|l|l|}
\hline Term used & Definition \\
\hline phase & A stage of the any life cycle corresponding to a certain level of ploidy e.g. the diploid phase. \\
\hline generation & $\begin{array}{l}\text { A stage of the life cycle of a multicellular organism during which somatic development takes } \\
\text { place e.g. the sporophyte generation (generation is used rather than phase in this case to avoid } \\
\text { confusion between sporophyte/gametophyte alternation and changes in ploidy as these two } \\
\text { processes are not necessarily correlated). Note, however, that other authors may have used } \\
\text { generation differently, to refer to a complete life cycle. }\end{array}$ \\
\hline gamete & $\begin{array}{l}\text { A reproductive cell capable of fusing with another gamete to produce a zygote. Note that } \\
\text { gametes of some species can also develop without sexual fusion (parthenogenesis). }\end{array}$ \\
\hline spore & A reproductive cell that is not capable of fusing with another cell. \\
\hline gametophyte & A gamete-producing plant \\
\hline sporophyte & A spore-producing plant. \\
\hline
\end{tabular}


Table 2. Genes required for normal gametophyte development in flowering plants. An asterisk

(*) indicates genes that act gametophytically. Those not marked with an asterisk either act sporophytically or both gametophytically and sporophytically. All genes are from Arabidopsis unless stated otherwise.

\begin{tabular}{|c|c|c|}
\hline Gene & Function & Reference \\
\hline \multicolumn{3}{|l|}{ Female gametophyte } \\
\hline PROLIFERA $(P R L) *$ & $\begin{array}{l}\text { Required for the first cell division during } \\
\text { megagametogenesis. Female specific. }\end{array}$ & Springer et al., 1995 \\
\hline$H A D A D(H D D) *$ & $\begin{array}{l}\text { Required for the first cell division during } \\
\text { megagametogenesis. Female specific. }\end{array}$ & Moore et al., 1997 \\
\hline LACHENSIS $(\text { LIS })^{*}$ & Restriction of gametic cell fate. & Gross-Hardt et al., 2007 \\
\hline GFA2 & Involved in synergid cell death. & Christensen et al., 2002 \\
\hline $\begin{array}{l}\text { CYTOKININ- } \\
\text { INDEPENDENT1 (CKI1) }\end{array}$ & Histidine kinase homolog required for megagametogenesis. & $\begin{array}{l}\text { Pischke et al., 2002; } \\
\text { Hejatko et al., } 2003\end{array}$ \\
\hline DYAD / SWITCHI & Female-specific arrest in meiosis I. & $\begin{array}{l}\text { Siddiqi et al., 2000; } \\
\text { Agashe et al., } 2002\end{array}$ \\
\hline NOMEGA & $\begin{array}{l}\text { Role in cell cycle progression during gametophyte } \\
\text { development. }\end{array}$ & $\begin{array}{l}\text { Kwee and Sundaresan, } \\
2003\end{array}$ \\
\hline $\begin{array}{l}\text { RETINOBLASTOMA } \\
\text { RELATED } 1 \text { (RBR1) }\end{array}$ & Cell cycle control during female gametogenesis. & Ebel et al., 2004 \\
\hline SLOW WALKERI (SWA1) & $\begin{array}{l}\text { Progression of the mitotic division cycles of the female } \\
\text { gametophyte is disrupted in the mutant. }\end{array}$ & Shi et al., 2005, \\
\hline $\begin{array}{l}\text { CHROMATIN } \\
\text { REMODELLING } \\
\text { PROTEIN } 11(\text { CHR11) }\end{array}$ & $\begin{array}{l}\text { Essential for haploid nuclear proliferation during } \\
\text { megagametogenesis. }\end{array}$ & $\begin{array}{l}\text { Huanca-Mamani et al., } \\
2005\end{array}$ \\
\hline $\begin{array}{l}\text { ARABINOGALACTAN } \\
\text { PROTEIN } 18 \text { (AGP18) }\end{array}$ & $\begin{array}{l}\text { Expressed specifically in cells that spatially and temporally } \\
\text { define the sporophytic to gametophytic transition and during } \\
\text { early stages of seed development; essential for the initiation } \\
\text { of female gametogenesis. }\end{array}$ & $\begin{array}{l}\text { Acosta-Garcia and Vielle- } \\
\text { Calzada, 2004) }\end{array}$ \\
\hline MYB98 & $\begin{array}{l}\text { Expressed exclusively in the synergid cells, mutations in this } \\
\text { gene affect only the female gametophyte. }\end{array}$ & Kasahara et al., 2005 \\
\hline $\begin{array}{l}\text { NUCLEAR FUSION } \\
\text { DEFECTIVE1 (NFD1) }\end{array}$ & $\begin{array}{l}\text { Required for karyogamy during female gametophyte } \\
\text { development. }\end{array}$ & Portereiko et al., 2006b \\
\hline $\begin{array}{l}\text { STERILE APETALA } \\
(S A P)\end{array}$ & $\begin{array}{l}\text { Transcription regulator involved in completion of } \\
\text { megasporocyte meiosis and in determining floral organ } \\
\text { number. }\end{array}$ & Byzova et al., 1999 \\
\hline FEM111 / AGL80 & $\begin{array}{l}\text { In fem } 111 \text { female gametophytes, the central cell's nucleolus } \\
\text { and vacuole fail to mature correctly. }\end{array}$ & Portereiko et al., 2006a \\
\hline AINTEGUMENTA (ANT) & Integuments missing in mutant and defects in female meiosis. & $\begin{array}{l}\text { Klucher et al., 1996; Elliot } \\
\text { et al., } 1996\end{array}$ \\
\hline$B E L L 1(B E L 1)$ & Integuments abnormal in the mutant. & Reiser et al., 1995 \\
\hline ELONGATE1 & $\begin{array}{l}\text { Maize gene, absence of meiosis II with one of the dyad cells } \\
\text { directly initiating megagametogenesis in the mutant. }\end{array}$ & $\begin{array}{l}\text { Barrell and Grossniklaus, } \\
2005\end{array}$ \\
\hline
\end{tabular}




\begin{tabular}{|c|c|c|}
\hline $\begin{array}{l}\text { INDETERMINATE } \\
\text { GAMETOPHYTE } 1(I G 1)\end{array}$ & $\begin{array}{l}\text { Maize gene that encodes a LOB domain protein required for } \\
\text { embryo sac and leaf development; restricts the proliferative } \\
\text { phase of female gametophyte development. }\end{array}$ & $\begin{array}{l}\text { Evans et al., } 2007 \\
\text { Huang and Sheridan, } 1996\end{array}$ \\
\hline $\begin{array}{l}\text { CONSTITUTIVE TRIPLE } \\
\text { RESPONSE (CTRL1) }\end{array}$ & $\begin{array}{l}\text { Ethylene-response mutant defective in female gametophyte } \\
\text { development. }\end{array}$ & Kieber et al 1993 \\
\hline $\begin{array}{l}\text { MULTIPLE } \\
\text { ARCHESPORIAL } \\
\text { CELLS1 (MAC1) }\end{array}$ & $\begin{array}{l}\text { Maize gene involved in the formation of multiple } \\
\text { archeosporial cells in ovules. }\end{array}$ & Sheridan et al., 1996 \\
\hline $\begin{array}{l}\text { GAMETOPHYTIC } \\
\text { FACTOR1-6 (GFA1-6) }\end{array}$ & Required for megagametogenesis. & Feldmann et al 1997 \\
\hline $\begin{array}{l}\text { GAMETOPHYTIC } \\
\text { FACTOR }(G F)\end{array}$ & Required for megagametogenesis. & $\begin{array}{l}\text { Redei } 1965 \text {; Christensen } \\
\text { et al } 1997\end{array}$ \\
\hline $\begin{array}{l}\text { FEMALE GAMETPHYTE } \\
1-4(\text { FEM1-4) }\end{array}$ & $\begin{array}{l}\text { fem } 1 \text { and fem } 2 \text { mutations affect only the female gametophyte, } \\
\text { while the fem } 3 \text { and fem } 4 \text { mutations affect both the female and } \\
\text { male gametophyte. }\end{array}$ & Christensen et al 1998 \\
\hline FEM5-38 & Mutation affects the female gametophyte. & Christensen et al., 2002 \\
\hline $\begin{array}{l}\text { LYSOPHOSPHATIDYL } \\
\text { ACYLTRANSPHERASE } 2 \\
(\text { LPAT2) }\end{array}$ & $\begin{array}{l}\text { Essential for female gametophyte development, expressed in } \\
\text { the male and female gametophyte. }\end{array}$ & Kim et al., 2005 \\
\hline \multicolumn{3}{|l|}{ Female/Male gametophyte } \\
\hline $\begin{array}{l}\text { SPOROCYTLESS (SPL)/ } \\
\text { NOZZLE (NZZ) }\end{array}$ & $\begin{array}{l}\text { Required for the production of male and female sporocytes; } \\
\text { MADS box-related transcription factor. }\end{array}$ & $\begin{array}{l}\text { Yang et al., 1999; } \\
\text { Schiefthaler et al., } 1999\end{array}$ \\
\hline $\begin{array}{l}\text { GLUCOSE 6- } \\
\text { PHOSPHATE/PHOSPHA } \\
\text { TE TRANSLOCATOR1 } \\
(\text { GPT1) }\end{array}$ & $\begin{array}{l}\text { Mutants show inability to complete pollen and ovule } \\
\text { development. }\end{array}$ & Niewiadomski et al., 2005 \\
\hline ASYNAPTIC1 (ASY1) & Mutant affected during male and female synapsis. & $\begin{array}{l}\text { Caryle et al., 2000; } \\
\text { Amstrong et al., } 2002\end{array}$ \\
\hline$U N G U D$ & Affects both male and female gametogenesis. & Lalanne et al 2004 \\
\hline SYN1/DIF1 & $\begin{array}{l}\text { Expressed specifically in male and female meiocytes, } \\
\text { encodes a protein that is similar to cyclins. }\end{array}$ & $\begin{array}{l}\text { Bai et al., 1999; Bhatt et } \\
\text { al., } 1999\end{array}$ \\
\hline SOLO DANCERS (SDS) & $\begin{array}{l}\text { Required for the interaction between homologous } \\
\text { chromosomes during meiotic prophase I (male and female } \\
\text { meiocytes). }\end{array}$ & Azumi et al., 2002 \\
\hline$A t D M C 1$ & $\begin{array}{l}\text { Abnormal meiosis in pollen mother cells and in megaspore } \\
\text { mother cells }\end{array}$ & $\begin{array}{l}\text { Klimyuk and Jones, 1997; } \\
\text { Couteau et al., } 1999\end{array}$ \\
\hline AtMND1 & Essential for male and female meiosis. & Kerzendorfer et al., 2006 \\
\hline \multicolumn{3}{|l|}{ Male Gametophyte } \\
\hline $\begin{array}{l}\text { STUD }(\text { STD }) \\
\text { /TETRASPORE }(T E S)\end{array}$ & Required for male meiotic cytokinesis. & $\begin{array}{l}\text { Hulskamp et al., } 1997 \\
\text { Spielman et al., } 1997\end{array}$ \\
\hline QUARTET $(Q R T)$ & Required for microspore separation. & $\begin{array}{l}\text { Rhee and Somerville, } \\
\text { 1998; Rhee et al., } 2003\end{array}$ \\
\hline $\operatorname{SIDECAR}(S C P)^{*}$ & $\begin{array}{l}\text { Required for the normal cell division pattern during pollen } \\
\text { development. }\end{array}$ & $\begin{array}{l}\text { Chen and McCormick, } \\
1996\end{array}$ \\
\hline TWO IN ONE (TIO) & Required for cytokinesis at pollen meiosis I. & Twell et al., 1998 \\
\hline $\begin{array}{l}\text { MORI/GEMINI } \\
\text { POLLEN1*(GEM1) }\end{array}$ & $\begin{array}{l}\text { Required for microspore polarity, division asymmetry and } \\
\text { involved pollen cell fate. }\end{array}$ & $\begin{array}{l}\text { Park et al., 1998; Twell et } \\
\text { al., } 2002\end{array}$ \\
\hline LIMPET POLLEN $(L I P)^{*}$ & Required for generative cell migration after pollen meiosis I. & Howden et al., 1998 \\
\hline
\end{tabular}




\begin{tabular}{|c|c|c|}
\hline $\begin{array}{l}\text { MALE GERM UNIT } \\
\text { DISPLACED }(M U D)^{*}\end{array}$ & \multirow[t]{2}{*}{$\begin{array}{l}\text { Required for the correct positioning of the male germ unit in } \\
\text { the mature pollen grain. }\end{array}$} & \multirow[t]{2}{*}{ Lalanne and Twell, 2002} \\
\hline $\begin{array}{l}\text { GERM UNIT } \\
\text { MALFORMED }(G U M)^{*}\end{array}$ & & \\
\hline SETH* & Essential for male progamic development. Male specific. & Lalanne et al 2004 \\
\hline HALFMAN $(H A M) *$ & Male gametophytic; required for pollen development. & Oh et al 2003 \\
\hline $\begin{array}{l}\text { SOMATIC } \\
\text { EMBRYOGENESIS } \\
\text { RECEPTOR KINASE1/2 } \\
(\text { SERK1/2) }\end{array}$ & $\begin{array}{l}\text { Required for tapetum development and microspore } \\
\text { maturation. }\end{array}$ & $\begin{array}{l}\text { Colcombet et al., 2005; } \\
\text { Albrecht et al., } 2005\end{array}$ \\
\hline $\begin{array}{l}\text { MALE } \\
\text { STERILE5(MS5)/TDM/PO } \\
\text { LLENLESS3 }\end{array}$ & $\begin{array}{l}\text { Mutations in } T D M \text { cause the formation 'polyads' (tetrads with } \\
\text { more than four pools of chromosomes after male meiosis). }\end{array}$ & Glover et al., 1998 \\
\hline $\begin{array}{l}\text { ARABIDOPSIS SPK1- } \\
\text { LIKE1 (ASK1) }\end{array}$ & $\begin{array}{l}\text { Essential for early nuclear reorganization events during } \\
\text { meiosis. }\end{array}$ & $\begin{array}{l}\text { Zhao et al., 2006; Yang et } \\
\text { al., } 2006\end{array}$ \\
\hline MALE STERILITY1 (MS1) & $\begin{array}{l}\text { Transcriptional regulator of male gametogenesis, mutant has } \\
\text { altered tapetal cell death and pollen wall development. }\end{array}$ & $\begin{array}{l}\text { Wilson et al., 2001; } \\
\text { Vizcay-Barrena et al., } \\
2006\end{array}$ \\
\hline $\begin{array}{l}\text { DEFECTIVE-POLLEN3/ } \\
\text { MEIOSIS1 (MEII) }\end{array}$ & $\begin{array}{l}\text { Chromosomes are fragmented during meiosis in the mutant } \\
\text { resulting in aberrant microspores. }\end{array}$ & $\begin{array}{l}\text { Sanders et al., 1999; He } \\
\text { and Mascarenhas, } 1998\end{array}$ \\
\hline $\begin{array}{l}\text { CYCLIN-DEPENDENT } \\
\text { KINASEA-1 (CDKA-1) }\end{array}$ & $\begin{array}{l}C d c 2 \text { homologue; essential for division of the generative cell } \\
\text { during male gametogenesis. }\end{array}$ & Iwakawa et al., 2006 \\
\hline $\begin{array}{l}\text { EXTRA SPOROGENOUS } \\
\text { CELLS (EXS)/EXCESS } \\
\text { MICROSPOROCYTES1 } \\
(\text { EMS1) }\end{array}$ & $\begin{array}{l}\text { Regulates germline cell number and tapetal identity, and } \\
\text { promotes seed development. }\end{array}$ & $\begin{array}{l}\text { Canales et al., 2002; Zhao } \\
\text { et al., } 2002\end{array}$ \\
\hline $\begin{array}{l}\text { DYSFUNCTIONAL } \\
\text { TAPETUM1 (DYT1) }\end{array}$ & $\begin{array}{l}\text { Controls anther development and function, } D Y T 1 \text { acts } \\
\text { downstream of SPL/NZZ and EMS1/EXS. }\end{array}$ & Zhang et al., 2006 \\
\hline $\begin{array}{l}\text { TAPETUM } \\
\text { DETERMINANT1 (TPD1) }\end{array}$ & Required for the tapetal cell fate. & Yang et al., 2003 \\
\hline $\begin{array}{l}\text { ABORTED } \\
\text { MICROSPORES (AMS1) }\end{array}$ & $\begin{array}{l}\text { MYC class transcription factor with a role in tapetal cell } \\
\text { development and the post-meiotic transcriptional regulation } \\
\text { of microspore development. }\end{array}$ & Sorensen et al., 2003 \\
\hline $\begin{array}{l}\text { UNDEVELOPED } \\
\text { TAPETUM1 (Udt1) (rice) }\end{array}$ & Rice gene required for the maturation of tapetal cells. & Jung et al., 2005 \\
\hline $\begin{array}{l}\text { GUS NEGATIVE1 } \\
(\text { GNE1) }\end{array}$ & Required for tapetum and middle-layer cell formation. & Sorensen et al., 2002 \\
\hline $\begin{array}{l}\text { MALE MEIOCYTE } \\
D E A T H(M M D) / D U E T\end{array}$ & Required for male meiosis. & $\begin{array}{l}\text { Reddy et al., 2003; Yang } \\
\text { et al., } 2003\end{array}$ \\
\hline DESYNAPTIC1 (DSY1) & Mutant affected during synapsis. & Ross et al., 1997 \\
\hline $\begin{array}{l}\text { PARTING DANCERS } \\
(P T D)\end{array}$ & Mutant has defective meiosis. & Wijeratne et al., 2006 \\
\hline SPO11 & $\begin{array}{l}\text { Disruption of } S P O 11 \text { causes defects in meiotic } \\
\text { recombination, synaptonemal complex formation and } \\
\text { bivalent formation. }\end{array}$ & Grelon et al., 2001 \\
\hline RAD50 & Involved in meiosis and DNA repair. & $\begin{array}{l}\text { Gallego et al., 2001; } \\
\text { Gallego and White, } 2001\end{array}$ \\
\hline MRE11 & $\begin{array}{l}\text { Mutant shows chromosome fragmentation and the absence of } \\
\text { synapsis in the initial stages of meiosis of pollen mother } \\
\text { cells. }\end{array}$ & Puizina et al., 2004 \\
\hline$B R C A 2$ & Involved in meiosis, interacts with $D C M 1, R A D 51$ and $D S S 1$. & Siaud et al., 2004; Dray et \\
\hline
\end{tabular}




\begin{tabular}{l|l|l}
\hline RARING-TO-GO $(R T G)^{*}$ & Pollen grains germinate precociously within the anther & $\begin{array}{l}\text { Johnson and McCormick } \\
2001\end{array}$ \\
\hline $\begin{array}{l}\text { TARDY } \\
\text { ASYNCHRONOUS }\end{array}$ & $\begin{array}{l}\text { Delayed and asynchronous cell divisions during male meiosis } \\
\text { producing dyad pollen (two gametophytes within one exine } \\
\text { wall) }\end{array}$ & Magnard et al., 2001 \\
\hline $\begin{array}{l}\text { MULTIPLE } \\
\text { SPOROCYTE1 (MSP1) }\end{array}$ & $\begin{array}{l}\text { Crucial roles in restricting the number of cells entering into } \\
\text { male and female sporogenesis and in initiating anther wall } \\
\text { formation in rice }\end{array}$ & Nonomura et al., 2003 \\
\hline
\end{tabular}

